Article

\title{
Lignin Modification Supported by DFT-Based Theoretical Study as a Way to Produce Competitive Natural Antioxidants
}

\author{
Liga Lauberte ${ }^{1}$, Gabin Fabre ${ }^{2}{ }^{\mathbb{D}}$, Jevgenija Ponomarenko ${ }^{1}$, Tatiana Dizhbite ${ }^{1}$, \\ Dmitry V. Evtuguin ${ }^{3}{ }^{(D}$, Galina Telysheva ${ }^{1, *}$ and Patrick Trouillas ${ }^{2,4, *}$ \\ 1 Latvian State Institute of Wood Chemistry, Dzerbenes Str. 27, LV-1006 Riga, Latvia; roze@edi.lv (L.L.); \\ jevgenijaponomarenko@inbox.lv (J.P.); lcl@edi.lv (T.D.) \\ 2 INSERM UMR 1248, Université de Limoges, Faculté de Pharmacie, 2 rue du Docteur Marcland, \\ 87025 Limoges Cedex, France; gabin.fabre@gmail.com \\ 3 CICECO/University of Aveiro, Campus Universitário de Santiago, 3810-193 Aveiro, Portugal; dmitrye@ua.pt \\ 4 Regional Centre of Advanced Technologies and Materials, Department of Physical Chemistry, Faculty of \\ Science, Palacký University, tř. 17 listopadu 12, 77146 Olomouc, Czech Republic \\ * Correspondence: ligno@edi.lv (G.T.); patrick.trouillas@unilim.fr (P.T.); Tel.: +371-67555916 (G.T.); \\ +33-519-564-251 (P.T.)
}

Received: 9 April 2019; Accepted: 8 May 2019; Published: 9 May 2019

check for updates

\begin{abstract}
The valorization of lignins as renewable aromatic feedstock is of utmost importance in terms of the use of sustainable resources. This study provides a deductive approach towards market-oriented lignin-derived antioxidants by ascertaining the direct effect of different structural features of lignin on the reactivity of its phenolic $\mathrm{OH}$ groups in the radical scavenging reactions. The antioxidant activity of a series of compounds, modeling lignin structural units, was experimentally characterized and rationalized, using thermodynamic descriptors. The calculated $\mathrm{O}-\mathrm{H}$ bond dissociation enthalpies (BDE) of characteristic lignin subunits were used to predict the modification pathways of technical lignins. The last ones were isolated by soda delignification from different biomass sources and their oligomeric fractions were studied as a raw material for modification and production of optimized antioxidants. These were characterized in terms of chemical structure, molecular weight distribution, content of the functional groups, and the antioxidant activity. The developed approach for the targeted modification of lignins allowed the products competitive with two commercial synthetic phenolic antioxidants in both free radical scavenging and stabilization of thermooxidative destruction of polyurethane films.
\end{abstract}

Keywords: lignins; antioxidant activity; molecular rationalization; modification; stabilizers for polymers

\section{Introduction}

The lignocellulosic plant biomass has appeared a promising alternative to the fossil resources because of its abundance, renewability, versatility, and environmental safety. Lignin is one of the main components of plant biomass. However, unlike the polysaccharides, only a little amount of lignin is exploited to produce biobased chemicals so far [1-6].

Lignins are arranged as amorphous network polymers, as a result from the dehydrogenative radical polymerization of monolignols ( $\mathrm{p}$-coumaryl, coniferyl, and sinapyl alcohols), containing divers functional groups and reactive sites, e.g., phenolic, aliphatic, or carboxylic $\mathrm{OH}$ groups, as well as substituted aromatic sites or $\mathrm{C}=\mathrm{C}$ bonds [7-9]. Due to stereo-hindered phenolic $\mathrm{OH}$ groups, lignins can be valorized as prospective antioxidants. Low toxicity and biodegradability properties of natural lignin-derived antioxidants make them a promising alternative to the synthetic analogs [10-13] in food, 
cosmetic, and pharmaceutical applications [10,11,14,15]. Applications of lignin-based antioxidants in composite materials have also been recognized [12,16-18]. Lignin functionalities exhibits effective radical scavenger effect to prevent autoxidation and depolymerization of cellulose in pulps and papers $[19,20]$. The incorporation of lignins into synthetic polymer systems can prevent them from excessive photo- and thermal oxidation. For example, the introduction of $0.5-10 \%(w / w)$ of lignins, isolated from the byproducts of the prehydrolysis of birch wood in polypropylene or recycled polypropylene, significantly increases its stability, in a synergic way with the commercial Irganox 1010 antioxidant [21].

The main factors which limit the commercial use of lignins as antioxidants are their high structural variability and variation in chemical composition, as well as the absence of clear guidance for structure-activity relationships, which would allow the control of their antioxidant activity. Some recent technological developments propose to separate lignin molecules into fractions with low polydispersity and well-defined properties [22-25]. Among such processes, solvent fractionation of technical lignins is an effective method allowing to select lignin antioxidants by regulating molecular mass, polarity, compatibility to a given substrate, and number of phenolic $\mathrm{OH}$ and other functionalities [22,23,26-32]. Despite the success of fractionation to enhance the antioxidant response, the lignin-derived antioxidants still cannot compete with commercial phenolic antioxidants [33-35].

Due to the incredibly complicated and irregular structure of lignins, the measure of their antioxidant capacity does not allow to evaluate the contribution of each structural fragment on this activity [36-38]. The constitution of a library of lignin fragments has enabled experimental studies of the structure-antioxidant activity relationship, which, for the first time, included some features of the side-chain structure of the phenylpropane subunits revealing major structural descriptors [33,34]. To improve the predictive character of these structure-activity relationships, the experimental data can also take advantage of theoretical chemistry data on various phenolic compounds [39-41]. A joint experimental and theoretical approach sounds particularly adapted to solve the problems of lignin chemistry and to develop the methods of lignins modification for enhancing of their antioxidant activity. Based on the previous experimental studies made for a diversity of technical lignins, a series of low-molecular weight phenolic fragments have been chosen, considered as being sufficiently representative to rebuild the response of the "lignin puzzle."

The aim of the present work was to obtain new quantitative information about the direct contribution of the different substituents on the side-chains of lignin structural units and the linkages between these units on the capacity of phenolic $\mathrm{OH}$ groups to scavenge free radicals and to develop the approach for lignins modification to enhance their antioxidant potential. Lignin modification was made based on data obtained by joining density functional theory (DFT) calculations and experimental measurements. Such targeted modification supports promotion of market-oriented natural antioxidants from renewable sources. The sulfur-free lignins isolated by the soda delignification from different plant sources and their fractions were examined as prospective raw materials. The antioxidant activity of lignin products was compared to that of commercially available phenolic antioxidants in terms of stable free radical scavenging activity and the ability to reduce the thermooxidative destruction of polyurethane films. Unlike commercial phenolic antioxidants, which significantly inhibit the biodegradation of the composite materials, antioxidants derived from soda lignins are not only biodegradable, but they can also catalyze the biological decomposition of the material into which they are introduced [13].

\section{Results and Discussion}

The antioxidant activity of lignins is mainly attributed to phenolic $\mathrm{OH}$ groups whose reactivity in redox reactions is modulated by $\mathrm{OCH}_{3}$ groups [20,42,43]. This study has been focused on the contribution to antioxidant activity of the guaiacyl phenylpropane unit with different substitution patterns including side-chains and bonds between the structural units, which are insufficiently characterized so far. Accordingly, the antioxidant activity of 19 lignin-derived structural units 
was evaluated (Figure 1), all bearing a guaiacyl moiety with various structural modulations, being considered as representative of lignin structural fragments [34]. A contribution of each of these structures to the antioxidant activity was examined to develop the most appropriate method for modifying lignin to enhance its antioxidant activity.

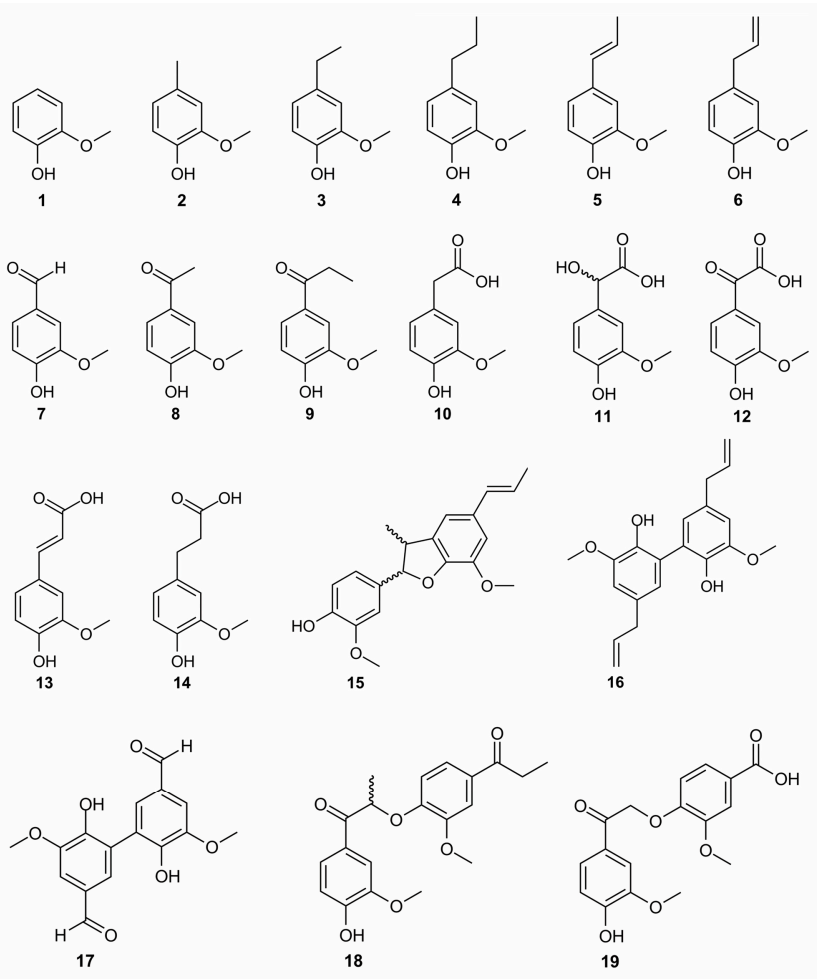

Figure 1. Chemical structures of the lignin model compounds.

To establish a reliable structure-activity relationship (SAR), the related mechanism of free radical scavenging should be considered. The basic antioxidant mechanism of polyphenolics is the direct ROS (reactive oxygen species) scavenging by hydrogen atom transfer (HAT) mainly from phenolic $\mathrm{OH}$ groups (Figure 2). HAT may proceed either via (i) proton-coupled electron transfer (PCET), which is the concerted electron and proton transfer from the polyphenol to the free radical, (ii) or by sequential proton loss-electron transfer (SPLET), which is electron transfer from the deprotonated form (mainly phenolate or carboxylate in the presence of carboxylic acid moieties). Electron transfer directly from the polyphenol (electron transfer then proton transfer, ET-PT) is unlikely [41], being much more favored from the deprotonated forms (SPLET).

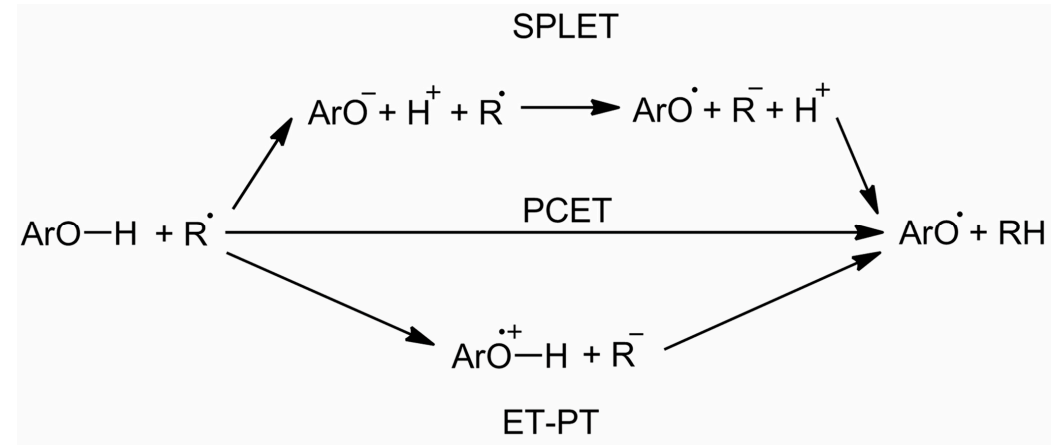

Figure 2. Different mechanisms for hydrogen atom transfer from polyphenols (ArO-H). 
Disregarding the mechanism involved, the free radical scavenging by polyphenols is mainly driven by bond dissociation enthalpies (BDEs) of phenolic $\mathrm{O}-\mathrm{H}$. This descriptor is indeed directly related to the thermodynamic balance of the scavenging process, which is similar for both PCET and SPLET mechanisms. Therefore, BDE is a global descriptor of the antioxidant activity. In turn, ETE is a descriptor more specific for SPLET: it has no relevance under apolar and acidic medium conditions, but it may be seen as a minor descriptor under polar and neutral to alkaline conditions i.e., when SPLET may proceeds. The calculated BDE values varied from $77.6 \mathrm{kcal}_{\mathrm{mol}}{ }^{-1}$ (typical for highly-reactive phenolic antioxidants) to $86.9 \mathrm{kcal}_{\mathrm{mol}} \mathrm{m}^{-1}$ (characteristic of low antioxidant activity), as shown in Table 1 . The scavenging of the $\mathrm{DPPH}^{\bullet}$ (2,2-diphenyl-1-picrylhydrazyl) and ABTS ${ }^{\bullet+}$ (2,2'-azino-bis(3-ethylbenzothiazoline-6-sulphonic acid) free radicals often correlates with these thermodynamic descriptors [44-46] Conversely to BDE, the higher the radical deactivation index (RDI) value, the higher the antioxidant activity. Wide variations of RDI values were observed, ranging from 0.02 to 1.72 and from 0.16 to 2.39 in DPPH $\mathrm{PH}^{\bullet}$ and ABTS $^{\bullet+}$ assays, respectively (Table 1). Assuming the RDI $=1.00$ for guaiacol (1) as a reference (Table 1$)$, RDI values lower or higher than 1.00 indicated a decrease or increase, respectively, in reactivity of the guaiacyl phenolic $\mathrm{OH}$ group.

Table 1. Calculated O-H bond dissociation enthalpy (BDE), electron transfer enthalpy (ETE), and radical deactivation indexes (RDI) in $\mathrm{DPPH}^{\bullet}$ and $\mathrm{ABTS}^{\bullet+}$ assays of the lignin modeling compounds.

\begin{tabular}{|c|c|c|c|c|c|c|}
\hline $\begin{array}{l}\text { Number of the } \\
\text { Compound }\end{array}$ & $\begin{array}{l}\text { Lignin Modeling } \\
\text { Compound }\end{array}$ & $\begin{array}{c}\text { BDE (kcal } \\
\text { mol-1) }^{-1}\end{array}$ & $\mathrm{DPPH}^{\bullet} \mathrm{RDI}$ & $\begin{array}{c}\text { ETE (kcal } \\
\text { mol-1) }^{-1}\end{array}$ & $\begin{array}{l}\text { ABTS } \bullet+ \\
\text { RDI }\end{array}$ & $\begin{array}{r}\mathrm{pK}_{\mathrm{a}} \text { in } \\
\text { Water }\end{array}$ \\
\hline 1 & guaiacol & 82.4 & $1.00 \pm 0.03$ & 109.0 & - & 9.93 \\
\hline 2 & methylguaiacol & 80.3 & $1.38 \pm 0.03$ & 105.7 & $0.92 \pm 0.03$ & 10.27 \\
\hline 3 & ethylguaiacol & 80.5 & $1.35 \pm 0.04$ & 106.0 & - & - \\
\hline 4 & propylguaiacol & 80.4 & $1.53 \pm 0.02$ & 106.0 & $1.58 \pm 0.07$ & 9.85 \\
\hline 5 & isoeugenol & 77.7 & $0.90 \pm 0.09$ & 105.7 & $0.67 \pm 0.05$ & 9.89 \\
\hline 6 & eugenol & 81.0 & $1.72 \pm 0.07$ & 107.3 & $0.96 \pm 0.04$ & 10.15 \\
\hline 7 & vanillin & 85.3 & $0.02 \pm 0.01$ & 121.4 & $0.57 \pm 0.03$ & 7.40 \\
\hline 8 & acetovanillone & 85.2 & $0.03 \pm 0.01$ & 119.5 & $0.54 \pm 0.03$ & 7.81 \\
\hline 9 & propiovanillone & 85.0 & $0.05 \pm 0.01$ & 118.9 & $0.45 \pm 0.04$ & 7.98 \\
\hline 10 & homovanillic acid & $82.0 / 78.7$ & $1.18 \pm 0.03$ & 109.1/102.0 & $1.67 \pm 0.02$ & $\begin{array}{c}4.41 / \\
10.52\end{array}$ \\
\hline 11 & vanillylmandelic acid & $82.5 / 79.0$ & $0.98 \pm 0.02$ & $111.3 / 103.3$ & $0.92 \pm 0.02$ & $\begin{array}{l}3.43 / \\
9.93\end{array}$ \\
\hline 12 & vanilglycolic acid & $86.9 / 83.7$ & $0.08 \pm 0.01$ & $125.7 / 116.7$ & $0.26 \pm 0.01$ & $\begin{array}{l}1.60 / \\
7.54\end{array}$ \\
\hline 13 & ferulic acid & $81.8 / 77.6$ & $1.23 \pm 0.03$ & $116.8 / 106.0$ & $2.39 \pm 0.07$ & $\begin{array}{l}4.56 / \\
9.39\end{array}$ \\
\hline 14 & dihydroferulic acid & $81.2 / 79.5$ & $1.23 \pm 0.06$ & $107.4 / 103.5$ & $1.39 \pm 0.04$ & - \\
\hline 15 & dehydrodiisoeugenol & 81.9 & $0.67 \pm 0.02^{\mathrm{a}}$ & 109.5 & - & - \\
\hline 16 & dehydrodieugenol & 80.1 & $2.72 \pm 0.03^{\mathrm{a}}$ & 106.3 & - & - \\
\hline 17 & divanillin & 84.8 & n.d. ${ }^{c}$ & 121.6 & $0.16 \pm 0.03$ & $\begin{array}{c}6.16 / \\
10.07\end{array}$ \\
\hline 18 & dipropiovanillone & 86.0 & $0.014 \pm 0.01$ & 122.0 & - & - \\
\hline 19 & acetovanillonylvanillic acid & $86.5 / 85.6$ & $0.02 \pm 0.01$ & $121.5 / 120.0$ & 0.26 & - \\
\hline
\end{tabular}

${ }^{a}$ imported from Bortolomeazzi, et al. [47]; ${ }^{\mathrm{b}}$ imported from Ragnar, et al. [48]; ${ }^{\mathrm{c}}$ the compounds insoluble in the reaction medium.

BDE values followed a trend similar to the RDI values of $\mathrm{DPPH}^{\bullet}$ and $\mathrm{ABTS}^{\bullet+}$, as evidenced by regression coefficients $\left(\mathrm{R}^{2}\right)$ of 0.63 and 0.48 , respectively. The regression analysis by excluding extreme cases (i.e., compounds 5 and 16) nearly reached an acceptable linear correlation $\left(R^{2}=0.89\right.$ and 0.72 , respectively). This confirms the relevance of $\mathrm{BDE}$ as the major descriptor of the antioxidant activity, as already seen for $\mathrm{DPPH}^{\bullet}$ scavenging activity of flavonoids [44-46].

\subsection{Role of the Alkyl Substituents}

With a BDE of $82.4 \mathrm{kcal} \mathrm{mol}^{-1}$, the unsubstituted guaiacol (1) is an efficient $\mathrm{DPPH}{ }^{\bullet}$ scavenger (Table 1). Compounds 2, 3, 4, and $\mathbf{6}$ (creosol, ethylguaiacol, propylguaiacol, and eugenol, respectively) exhibited higher antioxidant activity in both $\mathrm{DPPH}^{\bullet}$ and $\mathrm{ABTS}^{\bullet+}$ assays, as seen from the RDI value higher than 1.00 (Table 1). This result agrees with the corresponding BDE values, which are lower 
than $82.4 \mathrm{kcal} \mathrm{mol}^{-1}$ for these three compounds (Table 1). This effect can be attributed to a positive inductive effect of the alkyl chain thus increasing the electrophilicity of this lignin structural unit. The length of saturated alkyl chains (methyl, ethyl or propyl) had negligible effect on BDEs and DPPH ${ }^{\bullet}$ scavenging activity. Compounds 1-4 exhibited RDI values higher than 1 , meaning that more than one radical can be scavenged per $\mathrm{OH}$ group. This also means that these guaiacol derivatives may form oxidative products (e.g., dimers) also behaving as efficient scavengers. The spin density distribution of the aryloxy radicals formed after HAT from the guaiacyl moieties highlighted multiple reactive sites for the further dimerization reactions in solution (Figure 3).

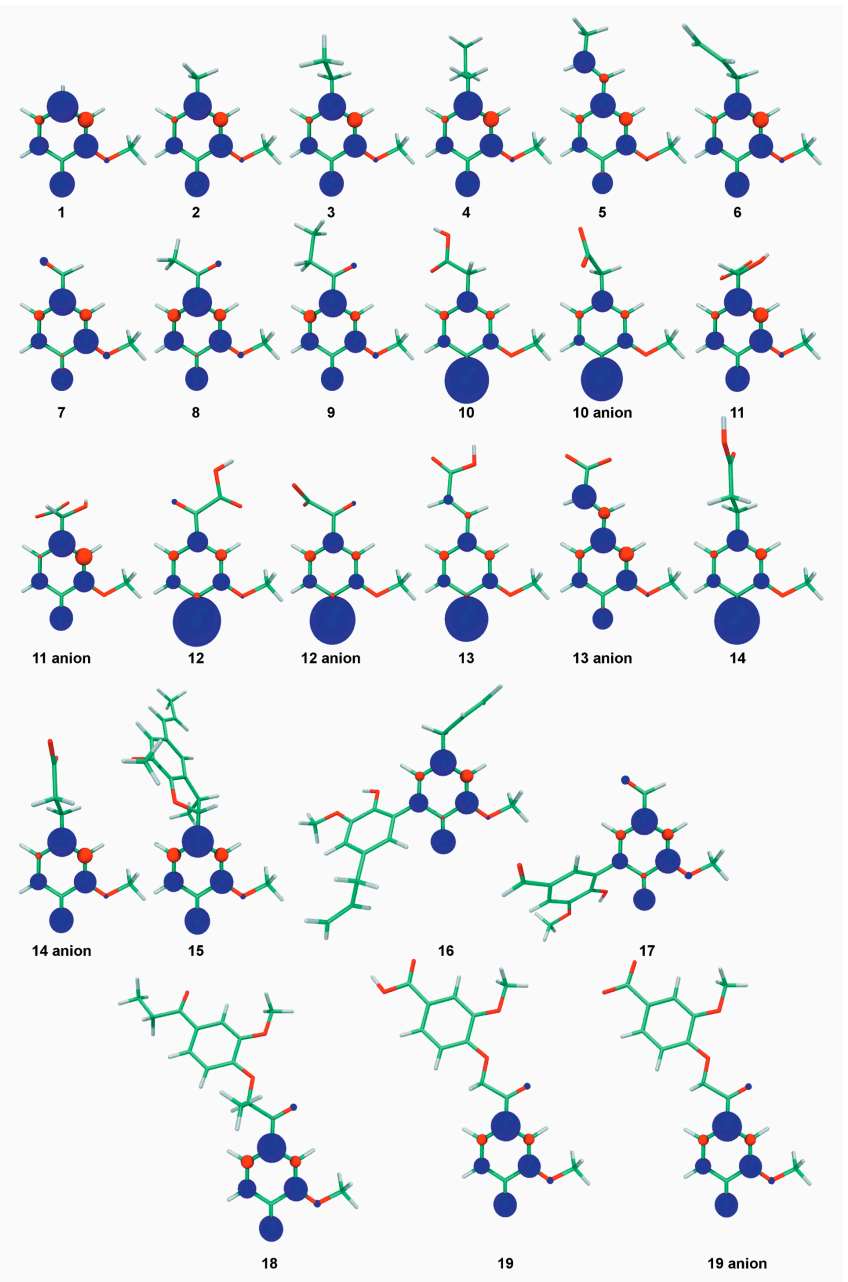

Figure 3. The spin density distribution of the aryloxyl radicals formed from the $\mathrm{OH}$ groups of the lignin-modeling structures.

\subsection{Role of $\pi$-Conjugation in the Side-Chain}

Compounds 5 and 6 are special cases because of possessing delocalized $\pi$ electrons in the side-chain at the para position to phenolic $\mathrm{OH}$ group. Both compounds differ from the location of the double bond (Figure 1). In 5, the double bond is conjugated with the phenyl ring, allowing the radical delocalization after HAT over the phenyl ring and the side-chain. The longer the delocalization, the more stable the radical, and the lower the BDE. Compound 5 indeed exhibits a low BDE value of $77.7 \mathrm{kcal} \mathrm{mol}^{-1}$ (Table 1). This makes 5 efficient at scavenging both $\mathrm{DPPH}^{\bullet}$ and $\mathrm{ABTS}^{\bullet+}$ free radicals. Bortolomeazzi and coauthors evidenced that 5 may form oxidatively-induced biphenyl dimers, following fast kinetics [47]. These dimers appeared 90 times less active than $\mathbf{5}$ in terms of antioxidant efficacy, most probably because of the lowering of electrophilicity by acquiring the electron-accepting substituent in the 5th position of the guaiacyl unit (i.e., increasing BDE values). This is confirmed by the O-H BDE 
of $81.9 \mathrm{kcal} \mathrm{mol}^{-1}$ as obtained for the most abundant dimer dehydrodiisoeugenol (15), as seen in Table 1. Some contradiction between a very low BDE and the RDI value lower than $\mathbf{1}$ of isoeugenol is therefore rationalized by the quick formation of less active isoeugenol dimers. The high rate constant of dimerization may also cause quick self-termination between two isoeugenol radicals, explaining the fact that its stoichiometric factor is lower than 1 against DPPH ${ }^{\bullet}$ [20]. The double bond in 6 is not conjugated with the phenyl ring, therefore decreasing the $\pi$-conjugated path compared to 5 . As a direct consequence, the BDE of the former is higher than that of the latter $\left(81.0\right.$ and $77.7 \mathrm{kcal} \mathrm{mol}^{-1}$, respectively). However, surprisingly, $\mathbf{6}$ is more active than $\mathbf{2}-\mathbf{4}$ at scavenging $\mathrm{DPPH}^{\bullet}$ (Table 1 ). Dimers can also be formed by two eugenolyl radicals [47]. The most abundant dimer, dehydrodieugenol (16), is approximately twice as active as the monomer (5) in terms of free radical scavenging. The BDE of 16 is $80.1 \mathrm{kcal} \mathrm{mol}^{-1}$, confirming its better activity. As steric hindrance may prevent planarity of the phenyl rings and extension of the $\pi$-conjugated path in the dimer, the increase in activity is mainly due to the presence of two phenolic OH groups, each one being prone to HAT and to efficient scavenge more than one free radical per one phenolic group. Additionally, 16 reacts quicker with $\mathrm{DPPH}^{\bullet}$ than 6 [47]. The 6 is therefore able to scavenge free radicals multiple times due to the formation of dimers, thus explaining the difference between its high BDE and the stoichiometric factors against DPPH ${ }^{\bullet}$.

Surprisingly, both 5 and $\mathbf{6}$ showed a similar and efficient antioxidant activity against ABTS ${ }^{\bullet+}$ (RDI values 1.45 and 1.44 for 5 and $\mathbf{6}$, respectively). This can be rationalized by the kinetically preferential SPLET mechanism in water. Both compounds exhibit low ETE values (105.7 and $107.3 \mathrm{kcal} \mathrm{mol}^{-1}$, respectively), which correlate with their efficient antioxidation activity in water against $\mathrm{ABTS}^{\bullet+}$.

\subsection{Role of the Carbonyl Group in the $\alpha$-Position of Guaiacyl Unit}

Vanillin, acetovanillone, and propiovanillone (7-9) are guaiacol derivatives substituted with a chain bearing a carbonyl group in the $\alpha$-position. These three compounds almost entirely lost DPPH ${ }^{\bullet}$ scavenging activity (Table 1) and exhibited high BDE values ranging from 85.0 to $85.3 \mathrm{kcal} \mathrm{mol}^{-1}$. The carbonyl group, being highly electronegative, attracts the density of electrons, thus reducing the $\pi$-conjugation and the stability of the aroxyl radical (Figure 3 ).

The length of the side-chain (one to three carbon atoms for 7 to 9) had no influence on BDEs and antioxidant activities. Interestingly, these three compounds still exhibited ABTS ${ }^{\bullet+}$ scavenging activities (0.57, 0.54, and 0.45 for 7, 8, and 9, respectively). As expected from the high BDE values, these activities were rather low, much lower than that of compounds 1-6. The discrepancy between both assays may come from the thermodynamic balance of scavenging reactions. In the case of $\mathrm{DPPH}^{\bullet}$, DPPH-H exhibits a BDE of $80.4 \mathrm{kcal} \mathrm{mol}^{-1}$ in polar solvent [42], hence HAT from compounds 7-9 to $\mathrm{DPPH}^{\bullet}$ is thermodynamically unlikely, therefore forbidding almost all primary scavenging action. Moreover, compounds 7, 8, and 9 have pKa of 7.40, 7.81, and 7.98 (Table 1), reflecting acidity of the phenolic $\mathrm{OH}$ group. In buffered solution ( $\mathrm{pH}=7.35$, see Experimental section), this corresponds to the presence of $44 \%, 11 \%$, and $5 \%$ phenolates (deprotonated forms of the phenolic compounds), for the three compounds, respectively. Therefore, the SPLET mechanism may also proceed, as reflected by the ETE descriptors. Indeed, ABTS $^{\bullet+}$ electron affinity is $-131 \mathrm{kcal} \mathrm{mol}^{-1}$ and the ETE values of 7, 8, and 9 are $121.4,119.5$, and $118.9 \mathrm{kcal} \mathrm{mol}^{-1}$, respectively.

\subsection{Role of the Carboxylic Group in the $\beta$-Position of Guaiacyl Unit}

Homovanillic acid (10) and vanillylmandelic acid (11) are guaiacyl derivatives substituted with a chain containing a carboxylic acid in $\beta$-position. The $\mathrm{pK}_{\mathrm{a}}$ of both compounds are 4.41 and 3.43, respectively, in water solution corresponding to the carboxylic acid group [48]. Thus, in all assays assessed in water, such as the ABTS $^{\bullet+}$ assay, the monoanionic form must be considered for interpretation. In pure methanol, the carboxylic acid $\mathrm{pK}_{\mathrm{a}}$ of both compounds is higher than 9 [49]. Therefore, concerning the $\mathrm{DPPH}^{\bullet}$ assay performed in methanol, the protonated form is predominant. The antioxidant activity of $\mathbf{1 0}$ and $\mathbf{1 1}$ is similar to that of $\mathbf{1}$ (RDI of 1.18 and 0.98 for both compounds, respectively, as depicted in Table 1). Compound $\mathbf{1 0}$ appears slightly more active than $\mathbf{1}$ and $\mathbf{1 1}$, 
in agreement with slightly lower BDE values (BDE of 82.0, 82.4, and $82.5 \mathrm{kcal}^{\mathrm{mol}}{ }^{-1}$ for the three compounds, respectively); however, both from theoretical and experimental points of view these differences are almost insignificant. In $\mathbf{1 0}$ and 11, the antioxidant constructive effect of the alkyl chain appears counterbalanced by the antioxidant destructive effect of the carboxylic acid moiety. It is worth noting that the hydroxyl group in the $\alpha$-position of $\mathbf{1 1}$ has a slight detrimental effect. Low phenolic BDEs for the monoanionic forms $\left(78.7\right.$ and $79.0 \mathrm{kcal} \mathrm{mol}^{-1}$ for $\mathbf{1 0}$ and 11, respectively) rationalized the rather high $\mathrm{ABTS}^{\bullet+}$ scavenging (RDI of 1.67 and 0.92, respectively). The slightly lower BDE of 10 may explain its somewhat better activity with respect to 11, however this difference is not very significant. A better explanation is given by ETE, which appears slightly lower for $\mathbf{1 0}$ than for $\mathbf{1 1}$. This confirms, at least partially, the contribution of SPLET mechanism, i.e., facilitated electron transfer from the carboxylated form to ABTS ${ }^{\bullet+}$. Vanilglycolic acid (12) bears both the properties of a carbonyl group in $\alpha$-position and a carboxylic acid in the $\beta$-position. This compound has no scavenging activity against $\mathrm{DPPH}^{\bullet}$, which is fully supported by the high $\mathrm{O}-\mathrm{H}$ BDE value $\left(86.9 \mathrm{kcal} \mathrm{mol}^{-1}\right)$. In water, $\mathbf{1 2}$ has two low $\mathrm{pK}_{\mathrm{a}}\left(\mathrm{pK}_{\mathrm{a}} 1=1.60\right.$ and $\mathrm{pK}_{\mathrm{a}} 2=7.54$ [43]), meaning that in the $\mathrm{ABTS}^{\bullet+}$ assay, this compound is mainly mono-deprotonated (carboxylate) and slightly bi-deprotonated (carboxylate and phenolate). The first ETE value (energy required to remove an electron from the carboxylate) is high thus making SPLET inefficient. The second ETE (energy required to remove an electron from the phenolate) is significantly lower, allowing SPLET towards $\mathrm{ABTS}^{\bullet+}$. Therefore, the remaining ABTS ${ }^{\bullet+}$ scavenging activity is most probably due to the small percentage of bi-deprotonated form of $\mathbf{1 2}$.

\subsection{Role of the Carboxylic Group in the $\gamma$-Position of Guaiacyl Unit}

Ferulic acid (13) is a very well-known antioxidant polyphenol. Experimentally, it showed very good $\mathrm{DPPH}^{\bullet}$ scavenging activity $(\mathrm{RDI}=1.23)$, in agreement with previously reported values $[50,51]$. Its dihydrogenated analog dihydroferulic acid (14) exhibits the same $\mathrm{DPPH}^{\bullet}$ scavenging activity. As for compounds with carboxylic acid moieties in $\beta$-position, these compounds exhibit low $\mathrm{pK}_{\mathrm{a}}$ values in water (4.56 for 13) but their $\mathrm{pK}_{\mathrm{a}}$ values in methanol are expected to be much higher [49]. Therefore, 13 and $\mathbf{1 4}$ are most likely present in their protonated form in methanol. Hence, the similar BDEs of the protonated forms ( 81.8 and $81.1 \mathrm{kcal} \mathrm{mol}^{-1}$, respectively) rationalize similar DPPH ${ }^{\bullet}$ scavenging activities for both compounds behaving by PCET. In water, both $\mathbf{1 3}$ and $\mathbf{1 4}$ are deprotonated from the carboxylic acid moieties (first $\mathrm{pK}_{\mathrm{a}}$ value is 4.56 for $\mathbf{1 3}$ [48]). Therefore, the higher antioxidant activity of $\mathbf{1 3}$ against $\mathrm{ABTS}^{\bullet+}$ can be explained by the BDE of its deprotonated form (ferulate, BDE of $77.6 \mathrm{kcal} \mathrm{mol}^{-1}$ ) compared to $\mathbf{1 4}$ (dihydroferulate, BDE of $79.5 \mathrm{kcal} \mathrm{mol}^{-1}$ ). Additionally, the larger $\pi$-conjugated path (delocalization of electron density) in ferulate with respect to dihydroferulate also accounts for the higher activity of ferulate. In their respective radical forms, the spin density of the radical is only located on the phenyl ring for dihydroferulatoxyl radical, whereas it also spans the conjugated side-chain for ferulatoxyl radical (Figure 3). A higher delocalization of the spin density induces higher stability of the radical, thus in agreement with lower BDE and higher antioxidant activity. It should be noted that the effect of the $\pi$-conjugation is different in $\mathbf{1 3}$ and $\mathbf{1 4}$, compared to 5 and 6 , due to the presence of the carboxylic moiety.

\subsection{Effect of Dimerization}

Compound 17 (divanillin) is the C5-C5 dimer formed from two vanillin molecules (Figure 1). It possesses two active symmetrical $\mathrm{OH}$ groups. Compounds 18 and $\mathbf{1 9}$ are arylether guaiacol dimers found in lignins. In both cases, the two guaiacyl units are $\beta-O-4$ 'linked. Thus, both compounds have only one active phenolic $\mathrm{OH}$ group. These three dimers exhibit carbonyl moieties in $\alpha$-position on their para side-chains, so they share the same properties as their corresponding monomers (compounds 7 and 8 ). Moreover, no additional $\pi$-conjugation arises from the dimerization process, even for divanillin in which steric hindrance prevents coplanarity of both phenyl rings. Therefore, these compounds show the absence or just weak activity against $\mathrm{DPPH}^{\bullet}$ and $\mathrm{ABTS}^{\bullet+}$, respectively, as confirmed by the high O-H BDE values $\left(84.8,86.0\right.$, and $86.5 \mathrm{kcal} \mathrm{mol}^{-1}$ for $\mathbf{1 7}, \mathbf{1 8}$, and $\mathbf{1 9}$, respectively). It is worth noting that 
even though 19 has a carboxylic acid moiety that can be deprotonated in solution, it is located on the guaiacyl moiety without the active $\mathrm{OH}$ group so with almost no influence on the BDE (Table 1).

\subsection{Quantification of the Direct Influence of the Each Structural Descriptor on the Antioxidant Activity} of Lignins

Since BDE allows direct describing of the structure-antioxidant activity relationship, this parameter was chosen to quantify the contribution of each structural descriptor. For this purpose $\triangle B D E$ values were calculated among derivatives with or without of the corresponding chemical pattern (Table 2). The $\triangle B D E$ was calculated for each pair of compounds shown in Table 2 and the average $\triangle B D E$ value of the involved pairs of compounds was taken for each structural descriptor (Table 2).

Table 2. Quantitative evaluation of the impact of different structural descriptors (chemical substituents) on the reactivity of the guaiacyl $\mathrm{OH}$ group.

\begin{tabular}{|c|c|c|c|c|}
\hline $\begin{array}{l}\text { Structural } \\
\text { Descriptor }\end{array}$ & $\begin{array}{l}\text { Compounds with and } \\
\text { without the Indicated } \\
\text { Chemical Feature }\end{array}$ & $\begin{array}{c}\text { Average } \Delta \text { BDE of Phenolic } \\
\text { OH Group between } \\
\text { Compounds Bearing or not } \\
\text { the Corresponding } \\
\text { Chemical Substituent }\end{array}$ & $\begin{array}{c}\text { Normalized } \\
\text { Negative Impact } \\
\text { of the Structural } \\
\text { Descriptor, } \%\end{array}$ & $\begin{array}{c}\text { Normalized } \\
\text { Positive Impact of } \\
\text { the Structural } \\
\text { Descriptor, } \%\end{array}$ \\
\hline$\alpha-\mathrm{CH}_{2}$ & $2(1)$ & -2.1 & - & 43 \\
\hline$\alpha-\mathrm{CH}_{2}-\mathrm{CH}_{3}$ & $3(1)$ & -1.9 & - & 39 \\
\hline$\alpha-\mathrm{CH}_{2}-\mathrm{CH}_{2}-\mathrm{CH}_{3}$ & $4(1)$ & -2.0 & - & 41 \\
\hline$\alpha-C=C$ & $5(4), 13(14)$ & -2.3 & - & 47 \\
\hline$\beta-C=C$ & $6(4)$ & +0.6 & 12 & - \\
\hline$\alpha-C=O$ & $7(2), 8(3), 9(4), 12(10)$ & +4.8 & 98 & - \\
\hline$\beta-\mathrm{COOH}$ & $10(3), 12(8)$ & +1.6 & 33 & - \\
\hline$\gamma-\mathrm{COOH}$ & $14(4)$ & +0.8 & 16 & - \\
\hline$\alpha-\mathrm{OH}$ & $11(10)$ & +0.5 & 10 & - \\
\hline$\alpha-O-4 / \beta-5$ & $15(4)$ & +1.5 & 31 & - \\
\hline$\beta-O-4$ ether linked & $18(9), 19(8)$ & +1.4 & 29 & - \\
\hline biphenyl (5-5) & $16(6), 17(7)$ & -0.7 & - & 14 \\
\hline
\end{tabular}

* model structures are depicted in Figure 1. Parent basic lignin structures are presented in parentheses.

The presence of $\alpha$-carbonyl group affects the reactivity of phenolic $\mathrm{OH}$ group much stronger in comparison to other structural descriptors, as can be seen by the biggest increase of BDE (highest $\triangle \mathrm{BDE}$ value) (Table 2 ). This rationalizes that compounds containing $\alpha$-carbonyl groups are almost inactive at scavenging $\mathrm{DPPH}^{\bullet}$ radicals (e.g., RDI of compound 7 was 0.02 , see Table 1). Because of this on/off effect, the $\triangle \mathrm{BDE}$ of $\alpha$-carbonyl groups was taken as a reference to normalize the impact of the other descriptors (Table 2).

\subsection{Experimental Evaluation of Lignin Antioxidant Activity with Respect to Impact of Different Structural Descriptors}

The quantitative impact of different structural descriptors (chemical substituents) on the reactivity of the guaiacyl $\mathrm{OH}$ group (Table 2) was used to rationalize the antioxidant activity of the oligomeric and polymeric lignin products and to find the most appropriate way for modification of technical lignins to obtain highly efficient phenolic antioxidants. Soda lignins used as a raw material in this study are heterogeneous both from point view of their chemical composition and the structure with a rather broad molecular weight distribution. Regarding the practical application of these antioxidants, numerous studies have highlighted the advantage of isolation of relatively uniform lignin fractions for these purposes, e.g., obtained by solvent fractionation. The most prospective approach is reported to obtain oligomeric fractions isolated from technical lignins by dichloromethane $\left(\mathrm{CH}_{2} \mathrm{Cl}_{2}\right)[22,23,26-29,31,32,35]$. Here, different soda lignins and their $\mathrm{CH}_{2} \mathrm{Cl}_{2}$ fractions were characterized in terms of the chemical composition, molecular weight distribution, content of functional groups, and other structural properties (Table 3). 
Table 3. Characterization of the lignin samples in terms of their composition, molecular weight distribution, functionality, and antioxidant activity.

\begin{tabular}{|c|c|c|c|c|c|c|}
\hline Sample & $\begin{array}{c}\text { Lignin } \\
\text { Content, } \% *\end{array}$ & $\mathrm{OCH}_{3}, \%$ & $\mathrm{M}_{\mathrm{w}}, \mathrm{Da}$ & $\begin{array}{c}\text { Phenolic } \\
\text { OH/100 Phenyl } \\
\text { Propane Units } \\
\text { (PPU) }\end{array}$ & $\begin{array}{c}\text { Relative Content of } \\
\alpha \text {-Carbonyl group in } \\
\text { the Phenyl-Propane } \\
\text { Units, \%** }\end{array}$ & $\begin{array}{c}\text { Number of } \\
\text { Scavenged DPPH } \\
\text { Radicals Per } \mathrm{OH}_{\text {phen }} \\
\text { (RDI) }\end{array}$ \\
\hline Flax soda lignin & $94.5 \pm 0.5$ & $8.1 \pm 0.1$ & 8358 & 26 & $9.1 \pm 0.1$ & $1.33 \pm 0.07$ \\
\hline Flax soda lignin $\mathrm{CH}_{2} \mathrm{Cl}_{2}$ fraction & $95.4 \pm 0.4$ & $6.5 \pm 0.1$ & 847 & 33 & $22.3 \pm 0.1$ & $0.71 \pm 0.04$ \\
\hline Black alder soda lignin & $74.0 \pm 0.7$ & $11.2 \pm 0.1$ & 7617 & 48 & $32.5 \pm 0.1$ & $0.77 \pm 0.03$ \\
\hline $\begin{array}{l}\text { Black alder soda lignin, } \mathrm{CH}_{2} \mathrm{Cl}_{2} \\
\text { fraction }\end{array}$ & $99.2 \pm 0.7$ & $24.0 \pm 0.2$ & 638 & 88 & $49.5 \pm 0.1$ & $0.69 \pm 0.03$ \\
\hline Ash-tree soda lignin & $92.0 \pm 0.9$ & $16.3 \pm 0.1$ & 4505 & 47 & $21.7 \pm 0.1$ & $1.01 \pm 0.05$ \\
\hline $\begin{array}{l}\text { Ash-tree soda lignin } \mathrm{CH}_{2} \mathrm{Cl}_{2} \\
\text { fraction }\end{array}$ & $98.2 \pm 0.5$ & $13.3 \pm 0.1$ & 818 & 85 & $39.9 \pm 0.1$ & $0.72 \pm 0.04$ \\
\hline TBHQ & - & - & - & 200 & - & $1.31 \pm 0.05$ \\
\hline Irganox & - & - & - & 100 & - & $1.31 \pm 0.07$ \\
\hline
\end{tabular}

* based on the results of Py-GC/MS analysis of lignin-derived and carbohydrate-derived products. ${ }^{* *}$ Relative content $(\%)$ of structures containing $\alpha$-carbonyl groups in all lignin-derived products, according to results of the Py-GC/MS analysis.

Their antioxidant activity was examined and compared to that of the synthetic antioxidants TBHQ and Irganox 1010 (Figure 4), which are highly effective and widely used commercial phenolic antioxidants.<smiles>CC(C)(C)c1cc(O)ccc1O</smiles>

TBHQ

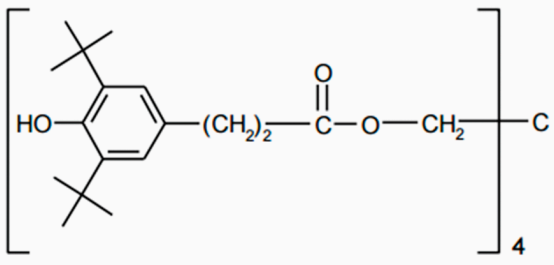

Irganox 1010

Figure 4. Chemical structures of the commercial antioxidants TBHQ and Irganox 1010, used as references.

Despite numerous advantages of $\mathrm{CH}_{2} \mathrm{Cl}_{2}$-fractioning, including a significantly higher content of phenolic $\mathrm{OH}$ moieties, lower heterogeneity in terms of composition, and the molecular weight distribution in comparison to the parent lignins, a noticeable part of phenolic $\mathrm{OH}$ groups in $\mathrm{CH}_{2} \mathrm{Cl}_{2}$ fractions is inactive in radical scavenging reactions (i.e., $\mathrm{RDI}<1$, see Table 3 ). The antioxidant activity assay of the oligomeric lignin $\mathrm{CH}_{2} \mathrm{Cl}_{2}$ fractions shows that they are not competitive in comparison to the commercial phenolic antioxidants TBHQ and Irganox (Table 3). This behavior could be explained by the negative effect of the structural descriptors mentioned in Table 2 within the lignin structure, being the $\alpha-\mathrm{C}=\mathrm{O}$ the most suspicious. Hence, this proposition was verified by more detailed analysis of lignins and the corresponding $\mathrm{CH}_{2} \mathrm{Cl}_{2}$ fractions.

\subsection{Rationalization and Enhancement of the Lignin Antioxidant Activity}

The analysis of lignins in strongly basic aprotic solvents allow to discriminate and quantify the phenolic hydroxyls in noncondensed and condensed structures [52,53]. As an example, the analysis of black alder lignin and its corresponding $\mathrm{CH}_{2} \mathrm{Cl}_{2}$ fraction is envisaged, but very similar features were find for other lignins in study. The ${ }^{1} \mathrm{H}-\mathrm{NMR}$ spectra in highly basic solution (HMPT- $\left.\mathrm{d}_{18}\right)$ show the difference between the black alder parent lignin and the corresponding $\mathrm{CH}_{2} \mathrm{Cl}_{2}$ fraction (Figure 5). 


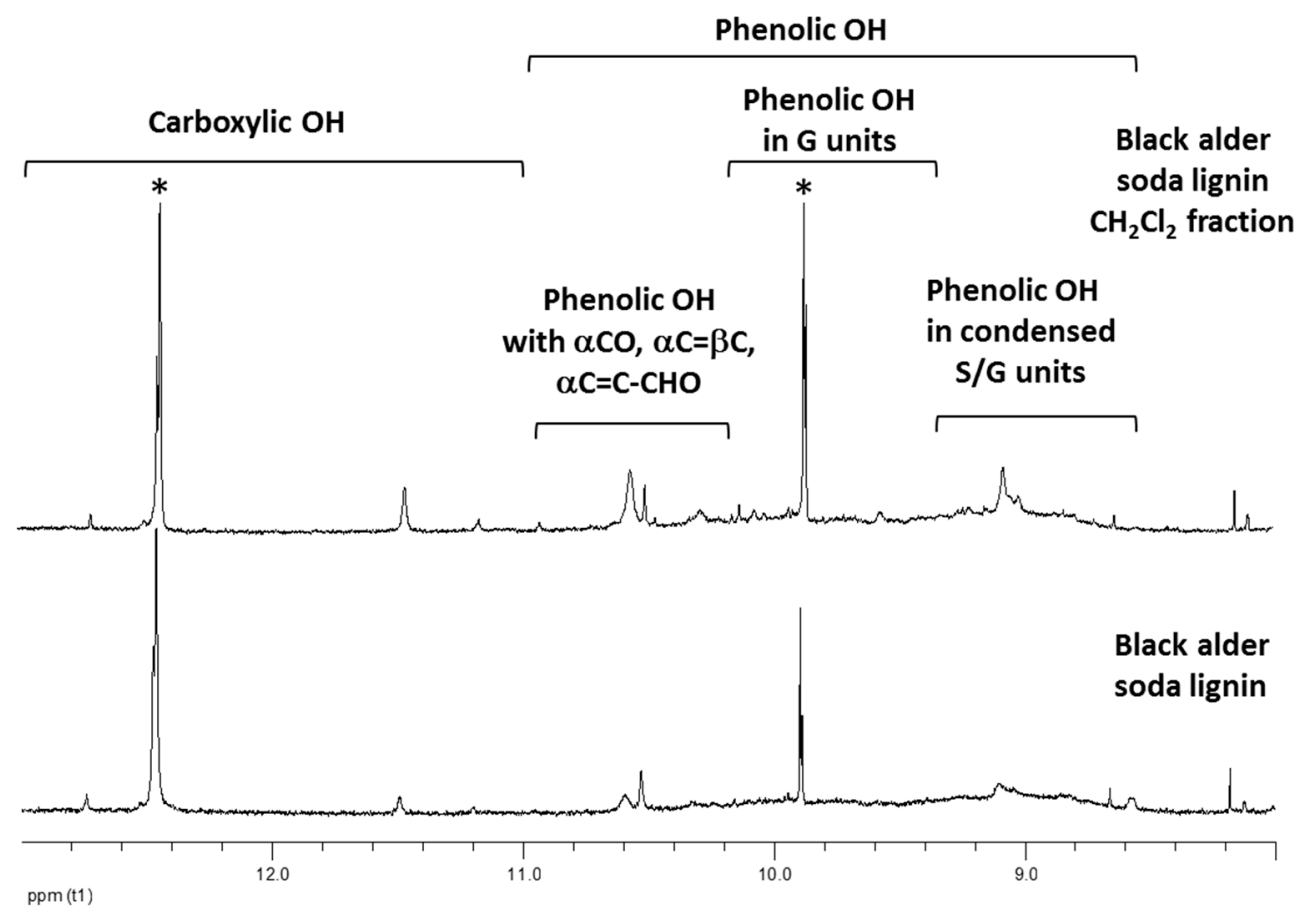

Figure 5. ${ }^{1} \mathrm{H}-\mathrm{NMR}$ spectra (HMPT-d18, 298K) of parent black alder soda lignin and its fraction, extracted by $\mathrm{CH}_{2} \mathrm{Cl}_{2}$. Solvent contaminants peaks are marked by asterisk.

The phenylpropane units containing phenolic $\mathrm{OH}$ revealed the characteristic resonances in the spectra range of 8.6 to $11.0 \mathrm{ppm}$ [52]. $\mathrm{CH}_{2} \mathrm{Cl}_{2}$ fraction showed an enhanced content of $\alpha$-carbonyl $(\alpha \mathrm{CO})$ (signal at 10.5-10.7 ppm [52]) and aldehyde groups (CHO) (signals at 10.2-10.4 ppm [52]) in the units containing the phenolic groups (Figure 5). They also have an increased content of carboxyl groups (signal at $11.46 \mathrm{ppm}$ [52]) in comparison to parent lignin. According to the data, obtained by density functional theory (DFT) calculations (Table 2), the presence of these oxygen-containing groups in the side-chain, especially carbonyl groups, is the major reason for the inactivation of lignin $\mathrm{CH}_{2} \mathrm{Cl}_{2}$ fractions in radical scavenging reactions. The results of ${ }^{1} \mathrm{H}-\mathrm{NMR}$ analysis were confirmed by the Py-GC/MS, which shows the significantly higher yield of $\alpha$-carbonyl group-containing compounds in the lignin derived products for $\mathrm{CH}_{2} \mathrm{Cl}_{2}$ fractions in comparison to the parent lignins (Table 3).

Due to the aforementioned structural features, the elimination of $\alpha$-carbonyl is prone to increase drastically the antioxidant activity of lignin fractions. To tackle this hypothesis, the chemical reduction of $\alpha$-carbonyl moieties was performed. The most commonly used reaction for the reduction of carbonyl groups of lignins is by using $\mathrm{NaBH}_{4}$; however, in such case the carbonyl groups are reduced to aliphatic $\mathrm{OH}$ groups which also have slightly negative effect on the antioxidant activity (Table 2). Instead, the chemical transformation of carbonyl groups into $\mathrm{CH}_{2}$ fragments would not only avoid the negative effect of the former but also bring the positive effect of the latter, see Table 2. Therefore, this modification of lignin products was performed according to the reaction sequence shown in Figure 6.

The elimination of the carbonyl groups was also controlled by FTIR spectroscopy (Figure 7). The variation of the intensity of the band assigned to the carbonyl groups vibration in the normalized spectra of flax, black alder, and ash-tree soda lignin $\mathrm{CH}_{2} \mathrm{Cl}_{2}$ fractions after their modification decreased from 76.2 to $19.5 \%$, from 29.7 to $11.3 \%$, and from 28.0 to $13.0 \%$, respectively (Figure 7 ).

The elimination of the carbonyl groups was also confirmed by Py-GC/MS showing a significant decrease in the yield of the lignin-derived compounds containing the carbonyl group with a simultaneous increase in the yield of the compounds containing $\alpha-\mathrm{CH}_{2}$ fragments (Figure 8). 


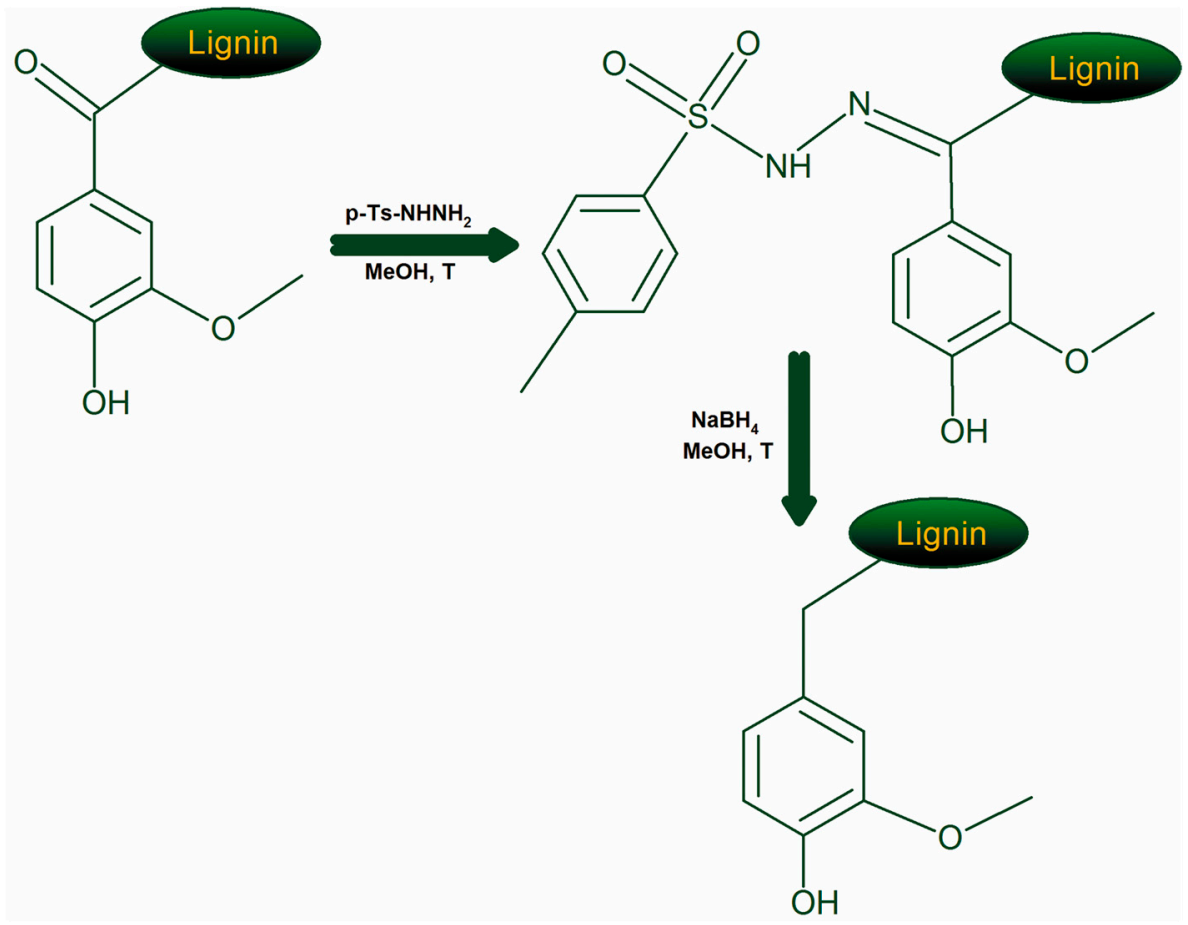

Figure 6. Reaction pathways used for the elimination of lignin carbonyl groups.

The decrease of the relative content of phenolic $\mathrm{OH}$ groups conjugated with carbonyl groups (with respect to the total $\mathrm{OH}$ phenolic) was also confirmed using differential UV/Vis spectroscopy (Table 4).

As it was predicted, the elimination of carbonyl groups drastically increases the reactivity of lignins phenolic $\mathrm{OH}$ groups making them competitive with respect to the commercial phenolic antioxidants TBHQ and Irganox 1010 (Table 4).

Table 4. Relative content of the phenolic units conjugated with $\alpha$-carbonyl group given with respect to the total $\mathrm{OH}$ phenolic and antioxidant activity of lignins.

\begin{tabular}{|c|c|c|}
\hline Sample & $\begin{array}{l}\text { Relative Content of the Phenolic } \\
\text { Units Conjugated with } \alpha \text {-Carbonyl } \\
\text { Group, vs. Total Phenolic Groups, \% }\end{array}$ & $\begin{array}{c}\text { Number of Scavenged DPPH• Radicals } \\
\text { Per One Phenolic OH Group }\end{array}$ \\
\hline Flax soda lignin $\mathrm{CH}_{2} \mathrm{Cl}_{2}$ fraction & 14.0 & $0.71 \pm 0.04$ \\
\hline $\begin{array}{c}\text { Flax soda lignin } \mathrm{CH}_{2} \mathrm{Cl}_{2} \text { fraction } \\
\text { modified }\end{array}$ & 6.0 & $2.05 \pm 0.8$ \\
\hline $\begin{array}{l}\text { Black alder soda lignin } \\
\qquad \mathrm{CH}_{2} \mathrm{Cl}_{2} \text { fraction }\end{array}$ & 36.5 & $0.69 \pm 0.03$ \\
\hline $\begin{array}{l}\text { Black alder soda lignin } \\
\mathrm{CH}_{2} \mathrm{Cl}_{2} \text { fraction, modified }\end{array}$ & 13.9 & $1.80 \pm 0.02$ \\
\hline $\begin{array}{l}\text { Ash-tree soda lignin } \mathrm{CH}_{2} \mathrm{Cl}_{2} \\
\text { fraction }\end{array}$ & 25.6 & $0.72 \pm 0.04$ \\
\hline $\begin{array}{c}\text { Ash-tree soda lignin } \\
\mathrm{CH}_{2} \mathrm{Cl}_{2} \text { fraction, modified }\end{array}$ & 11.3 & $1.26 \pm 0.07$ \\
\hline TBHQ & - & $1.31 \pm 0.05$ \\
\hline Irganox 1010 & - & $1.31 \pm 0.07$ \\
\hline
\end{tabular}




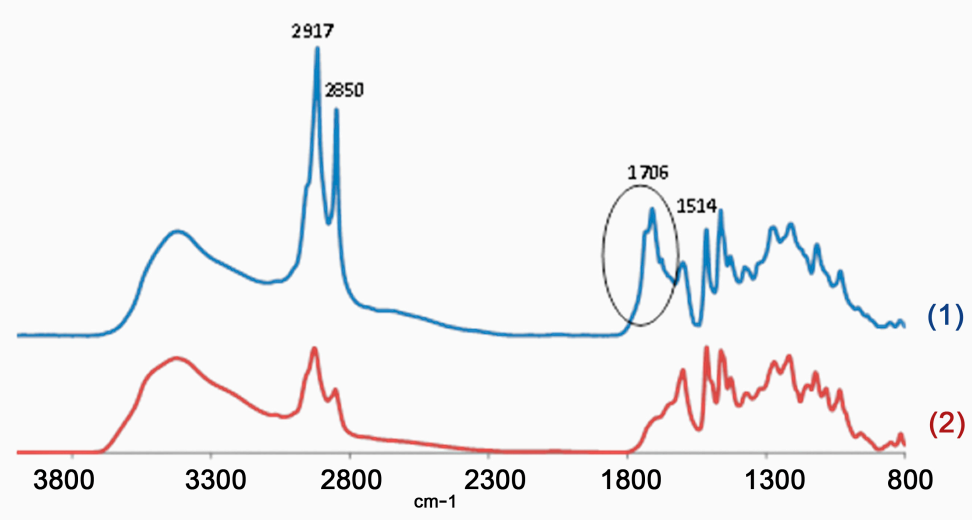

Flax soda lignin $\mathrm{CH}_{2} \mathrm{Cl}_{2}$ fraction (1)

Flax soda lignin $\mathrm{CH}_{2} \mathrm{Cl}_{2}$ fraction modified (2)

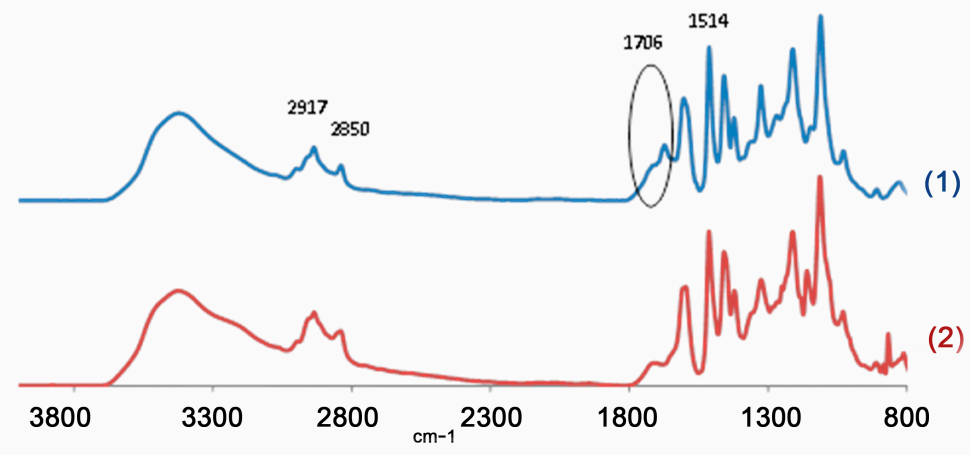

Black alder soda lignin $\mathrm{CH}_{2} \mathrm{Cl}_{2}$ fraction (1)

Black alder soda lignin $\mathrm{CH}_{2} \mathrm{Cl}_{2}$ fraction modified (2)

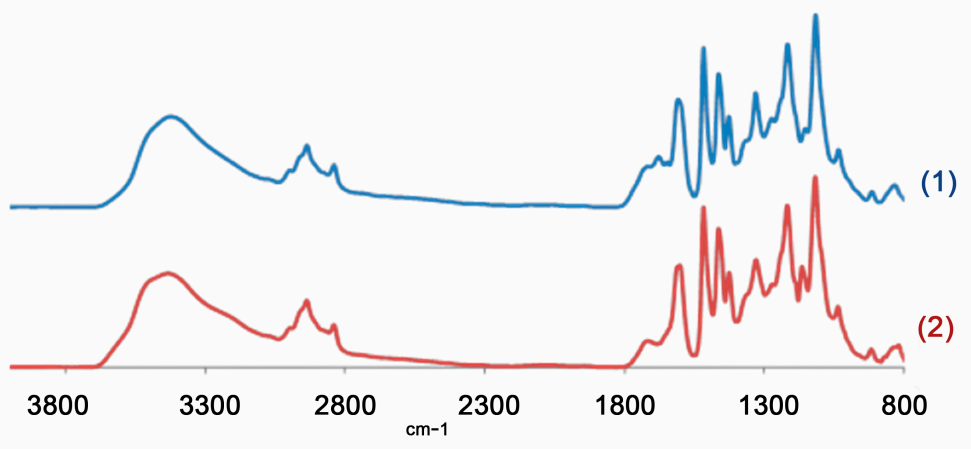

Ash tree soda lignin $\mathrm{CH}_{2} \mathrm{Cl}_{2}$ fraction (1)

Ash tree soda lignin $\mathrm{CH}_{2} \mathrm{Cl}_{2}$ fraction modified (2)

Figure 7. FTIR spectra of fractions obtained from soda lignins under study (1) before and (2) after their chemical modification (elimination of carbonyl groups). 

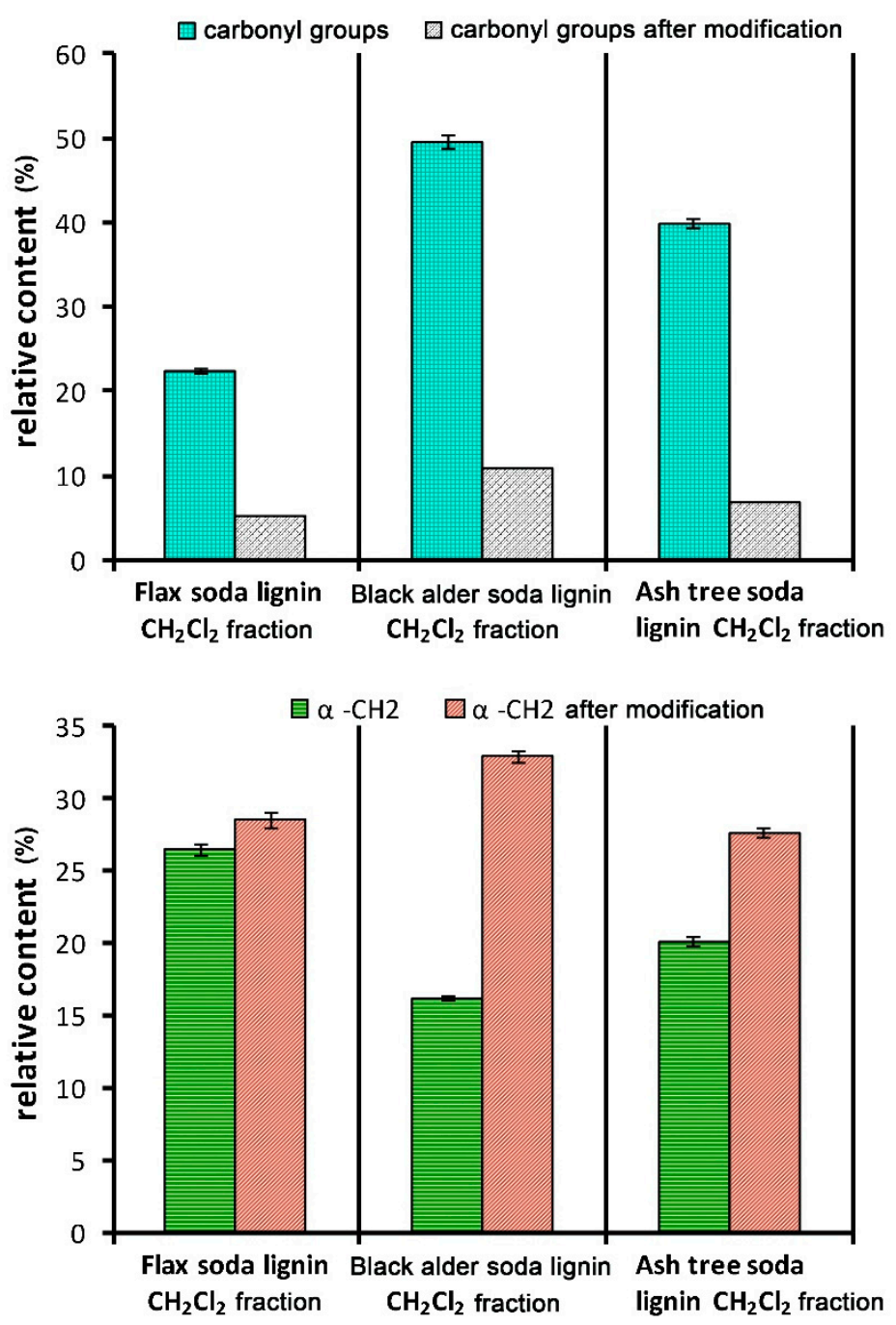

Figure 8. Change of the relative content of the compounds containing carbonyl groups $(\mathrm{C}=\mathrm{O})$ and $-\mathrm{CH}_{2}$ fragment at the $\alpha$-position of side-chain $\left(\alpha-\mathrm{CH}_{2}\right)$ in the lignin-derived compounds (Py-GC/MS data), caused by the modification of the $\mathrm{CH}_{2} \mathrm{Cl}_{2}$ fractions of soda lignins.

\subsection{Modified Lignin Fractions as Alternative Antioxidants in Polyurethane Films}

Commercially available synthetic antioxidants inhibit significantly the biodegradation of polymeric materials. Conversely, lignins can stimulate their decomposition under natural environment after the end of their service life. Therefore, replacing synthetic antioxidants with natural ones would promote the production of environmentally friendly materials. For example, it was shown that the addition of lignin (4.2\% to $9.3 \%$ in weight) in the poly(ethylene adipate) urethane films significantly improved their degradability by fungi enzymes (e.g., by laccase isolated from the Aspergillus sp.) [13].

In this work, the influence of different antioxidants on thermooxidative destruction of polyurethane (PU) films at $310{ }^{\circ} \mathrm{C}$ in air was studied for the demonstration purposes. Accordingly, flax soda lignin modification products were compared to Irganox 1010, a highly effective antioxidant against thermooxidative degradation of polyurethanes [54]. The kinetic curves of the thermooxidative degradation of the polyurethane films show that the addition of the antioxidant decreases the weight loss rate, especially in the first stage of thermooxidation destruction (Figure 9), which proceeds by radical mechanism [55]. 


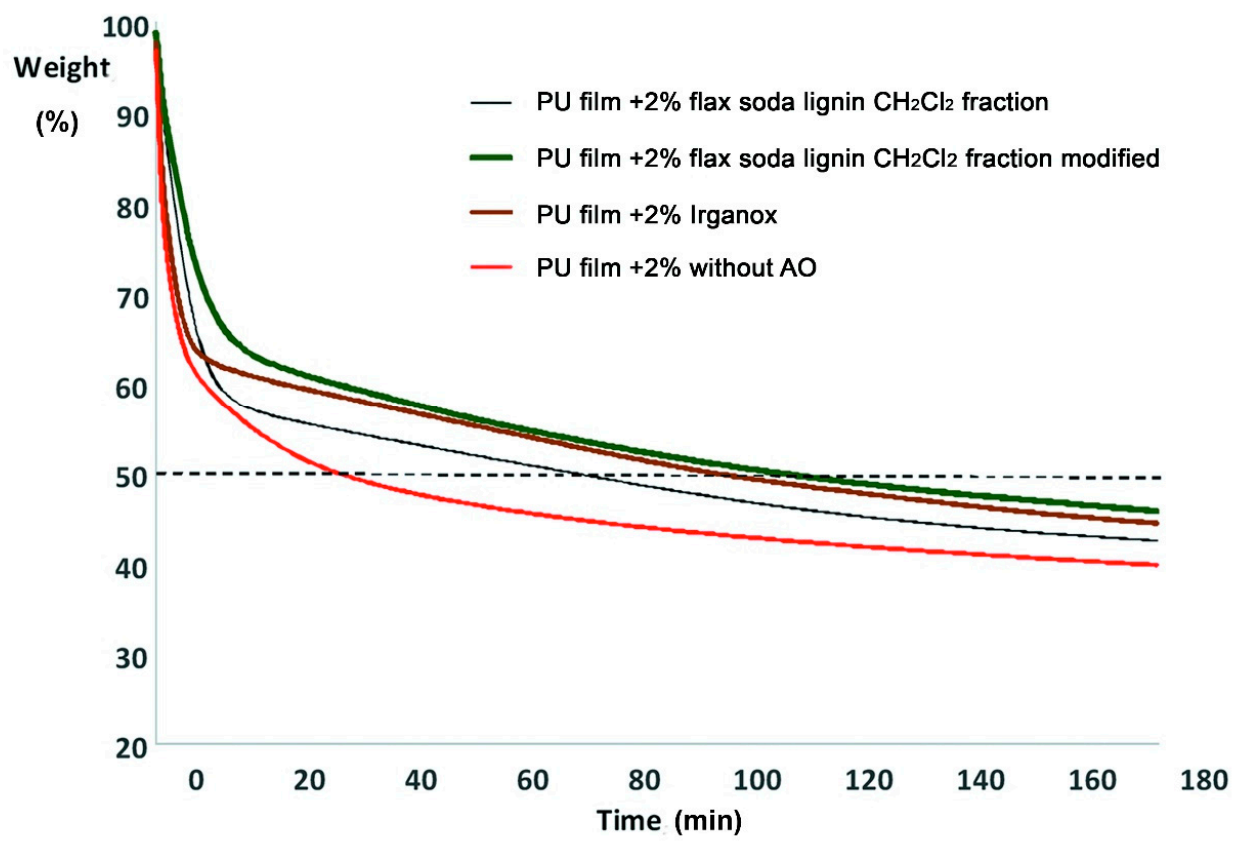

Figure 9. Kinetics of the thermooxidative degradation of polyurethane (PU) films (with and without addition of antioxidant).

Without antioxidant, $50 \%$ of the weight loss of the material is reached after $32.5 \mathrm{~min}$ of incubation. With $2 \%$ of flax soda lignin $\mathrm{CH}_{2} \mathrm{Cl}_{2}$ fraction $50 \%$ of the weight loss of the material is reached after $74.5 \mathrm{~min}$ of incubation. Adding $2 \%$ of Irganox or modified flax soda lignin $\mathrm{CH}_{2} \mathrm{Cl}_{2}$ fraction increases this time to 100 or $111.5 \mathrm{~min}$, respectively (Figure 9).

The antioxidant activity was also assessed as integrals of the kinetic curves (Figure 9). The integral antioxidant activity as portion from the activity of Irganox was 0.6 for flax soda lignin $\mathrm{CH}_{2} \mathrm{Cl}_{2}$ fraction and 1.3 for modified flax soda lignin $\mathrm{CH}_{2} \mathrm{Cl}_{2}$ fraction. This indicated that the modified flax soda lignin $\mathrm{CH}_{2} \mathrm{Cl}_{2}$ fraction performed $30 \%$ better inhibition effect than Irganox. This confirms a highly efficient antioxidant activity of this lignin derivative, and outlines the promising application of lignins in environmentally friendly materials.

\section{Materials and Methods}

\subsection{Compounds, Modeling Lignin Structural Units}

Model compounds $\mathbf{1 - 1 1}, \mathbf{1 3}, \mathbf{1 4}$, and $\mathbf{1 7}$ (Figure 1) used in this study are commercially available:

1.: 2-methoxyphenol (guaiacol), $\geq 98 \%$, Sigma Aldrich, CAS: 90-05-1

2.: 2-methoxy-4-methylphenol (4-methylguaiacol), $\geq 99 \%$, Acros organics, CAS 93-51-6

3.: 2-methoxy-4-ethylphenol (p-ethylguaiacol), $\geq 98 \%$, SAFC, CAS 2785-89-9

4.: 2-metoxy-4-propylphenol (4-propylguaiacol), $\geq 99 \%$, Sigma Aldrich, CAS 2785-87-7

5.: 2-methoxy-4-propenylphenol (isoeugenol), 99\%, Sigma Aldrich, CAS 97-54-1

6.: 4-allyl-2-methoxyphenol (eugenol), $\geq 98 \%$, Sigma Aldrich CAS 97-53-0

7.: 4-hydroxy-3-methoxybenzaldehyde (vanillin), 99\%, Sigma Aldrich, CAS 121-33-5

8.: 4'-hydroxy-3'-methoxyacetophenone (acetovanillone), 98\%, Acros organics, CAS498-01-2

9.: 1-(4-hydroxy-3-methoxyphenyl)-1-propanone (propiovanillone), $\geq 95 \%$, Bide Pharmatech, CAS 1835-14-9

10.: 4-hydroxy-3-methoxyphenylacetic acid (homovanilic acid), Acros organics, CAS 306-08-1

11.: (RS)-hydroxy(4-hydroxy-3-methoxy-phenyl)acetic acid (vanillylmandelic acid), 99\%, Acros organics, CAS 55-10-7 
13.: (E)-3-(4-hydroxy-3-methoxy-phenyl)prop-2-enoic acid (trans-ferulic acid), 99\%, Sigma Aldrich, CAS 537-98-4

14.: 3-(4-hydroxy-3-methoxyphenyl) propanoic acid (dihydroferulic acid), $\geq 96 \%$, Sigma Aldrich, CAS 1135-23-5

17.: 6,6'-dihydroxy-5,5'-dimethoxy-[1,1'-biphenyl]-3,3'-dicarboxaldehyde (divanillin), Fluorochem, CAS 2092-49-1

Compound 12 (4-hydroxy-3-methoxyphenyl)(oxo) acetic acid (or vanilglycolic acid) was synthesized at the Latvian State Institute of Wood Chemistry by the oxidation of compound 8 by nitrobenzene in alkaline medium at $100{ }^{\circ} \mathrm{C}$, using the method reported by Mottern [56] with minor modifications. Compound 8 (35 g), nitrobenzene $(27 \mathrm{~g})$, and $\mathrm{NaOH}(25 \mathrm{~g})$ were mixed in $75 \mathrm{~mL}$ water at $100{ }^{\circ} \mathrm{C}$ for $24 \mathrm{~h}$. Aniline and small amount of nitrobenzene were distilled with water vapor; the cooled solution was acidified, treated with active oxygen and filtered. The solution was cooled and compound 12 was crystallized. The amount of compound 12 was $34 \mathrm{~g}(85 \%)\left(\mathrm{T}_{\text {melting }}=133{ }^{\circ} \mathrm{C}\right)$ and its purity was $85 \%$, as checked chromatographically (GC, gas chromatography).

Compounds 18 and 19 (Figure 1) were synthesized by the methods described previously [57-59]. Their purity was 88 and 90\%, respectively, as checked by GC.

\subsection{High-Molecular Weight Lignins}

The soda sulfur-free lignins were produced on industrial scale from annual (nonwood) plants using the patented lignin precipitation process applied to black liquor from soda pulping [60]. Soda lignin from flax (Linum usitatissimum) was kindly supplied by the Granit SA (Lausanne, Switzerland).

The wood based soda lignins were obtained as a by-product from the black liquor of soda pulping (the IWC pilot equipment). The wood chips of black alder (Alnus glutinosa) and the ash-tree (Fraxinus excelsior) were pre-extracted with acetone to remove the extractives according to TAPPI standard T $280 \mathrm{pm}-99$. The residual content of the extractives was $0.15 \%$ on the oven-dried wood. The $280 \mathrm{~g}$ of chips were cooked in the digester with $2240 \mathrm{~mL}$ of $5 \%$ sodium hydroxide (Sigma Aldrich, Steinheim, Germany) which corresponds to an alkali charge of $42 \%$ based on the dry wood. Once the reactor reached the operating temperature of $160{ }^{\circ} \mathrm{C}$, it was maintained for $3 \mathrm{~h}$. The pulp was filtered, and the filtrate was acidified to $\mathrm{pH} 2$ to precipitate the lignin part. Lignin was filtered off and washed with a hot water until neutral reaction. The obtained lignin was dried under vacuum at $40{ }^{\circ} \mathrm{C}$. The yields of soda lignins from black alder and ash tree were $\sim 20 \%$.

Both industrial and laboratory lignins were used as raw materials for modification to obtain the highly effective lignin-derived antioxidants. The oligomeric fraction of lignin was obtained by fractionation with $\mathrm{CH}_{2} \mathrm{Cl}_{2}$ as described previously [61].

\subsection{Computational Methods}

The $\mathrm{O}-\mathrm{H}$ bond dissociation enthalpy (BDE) of each phenol moiety (ArO-H) was calculated based on the enthalpies balance as follows.

$$
\left.\mathrm{BDE}(\mathrm{ArO}-\mathbf{H})=\mathrm{H}^{0}\left(\mathrm{ArO}^{\bullet}\right)+\mathrm{H}^{0}\left(\mathbf{H}^{\bullet}\right)-\mathrm{H}^{0(} \mathrm{ArOH}\right)
$$

It is noteworthy that the lower the BDE, the easier the cleavage of the $\mathrm{O}-\mathrm{H}$ bond, and the higher the antioxidant activity. Similarly, the electron transfer enthalpy (ETE) was calculated as follows.

$$
\operatorname{ETE}\left(\mathrm{ArO}^{-}\right)=\mathrm{H}^{0}\left(\mathrm{ArO}^{\bullet}\right)-\mathrm{H}^{0}\left(\mathrm{ArO}^{-}\right)
$$

DFT calculations were performed with the B3P86 functional in Gaussian program as it was shown to accurately describe polyphenol BDEs [39,40,62,63]. The 6-31+G(d,p) basis set was used as providing very similar results compared to the larger and more computationally demanding $6-311+G(2 d, 3 p d)$ basis set. Ground-state geometries were confirmed by a vibrational frequency analysis that indicated the absence of imaginary frequency. Enthalpies were calculated at $298 \mathrm{~K}$ 
and $1 \mathrm{~atm}$. As many lignin fragments possess carboxylic acid moieties that can be deprotonated in aqueous media, all protonation states were evaluated. The solvent effect was considered using the integral-equation-formalism polarizable continuum model (IEF-PCM). Continuum models consider the molecular system embedded in a shape-adapted cavity surrounded by a dielectric continuum characterized by its permittivity ( $\varepsilon=32.61$ for methanol). Calculations in methanol reproduced the conditions of the DPPH${ }^{\bullet}$ assay. All calculations were performed with the Gaussian09 ${ }^{\circledR}$ software from Gauss Inc, USA [64].

\subsection{Antioxidant Activity Assays (DPPH ${ }^{\bullet}$, ABTS $\left.^{\bullet+}\right)$}

Chemicals used for the antioxidant evaluation (DPPH ${ }^{\bullet}, \mathrm{ABTS}^{\bullet+}$ and solvents) were of analytical grade (Sigma-Aldrich). All solutions were prepared freshly before the measurements.

$\mathrm{DPPH}^{\bullet}$ (2,2-diphenyl-1-picrylhydrazyl) was dissolved in methanol at a final concentration of $\sim 10-4 \mathrm{~mol} \mathrm{~L}^{-1}$ and incubated in the dark at room temperature for $16 \mathrm{~h}$. The exact concentration of $\mathrm{DPPH}^{\bullet}$ in terms of absorbency at $515 \mathrm{~nm}$ was calculated from a calibration curve $\left(\mathrm{A}_{515}=8.3 \times \mathrm{C}_{\mathrm{DPPH}}{ }^{\bullet}\right.$ $+0.001)$.

A stock solution of ABTS (2 mM) was prepared in $50 \mathrm{mM}$ phosphate buffered saline (PBS) made of $8.18 \mathrm{~g} \mathrm{NaCl}, 0.27 \mathrm{~g} \mathrm{KH}_{2} \mathrm{PO}_{4}, 3.58 \mathrm{~g} \mathrm{NaHPO}_{4} \times 11 \mathrm{H}_{2} \mathrm{O}$, and $0.15 \mathrm{~g} \mathrm{KCl}$ in $1 \mathrm{~L}$ of distilled water. When necessary, the $\mathrm{pH}$ of the solutions was adjusted at 7.4 with $0.1 \mathrm{M} \mathrm{NaOH}$. The ABTS ${ }^{\bullet+}$ solution was produced by mixing $50 \mathrm{~mL}$ of ABTS stock solution with $0.2 \mathrm{~mL}$ of $\mathrm{K}_{2} \mathrm{~S}_{2} \mathrm{O}_{8}(70 \mathrm{mM})$ aqueous solution. The mixture was kept in the dark at room temperature during hours 15 to 16 before use. To evaluate the antioxidant capacity, the $\mathrm{ABTS}^{\bullet+}$ solution was diluted with PBS to reach the absorbance at $734 \mathrm{~nm}$ of $0.800 \pm 0.030$ [65]. The exact concentration of $\mathrm{ABTS}^{\bullet+}$ was calculated from the calibration curve $\left(\mathrm{A}_{734}=23.85 \times \mathrm{C}_{\mathrm{ABTS}}{ }^{\bullet+}-0.007\right)$.

A $0.03 \mathrm{~mL}$ DMSO solution of the lignin or relative phenolic compounds was added to $3 \mathrm{~mL}$ of the prepared the $\mathrm{DPPH}^{\bullet}$ or the $\mathrm{ABTS}^{\bullet+}$ solution. Five different concentrations were used for each derivative. The decrease in $\mathrm{DPPH}^{\bullet}$ or $\mathrm{ABTS}^{\bullet+}$ concentration was followed at a 515 or $734 \mathrm{~nm}$ respectively until the reaction's completion using Perkin Elmer UV/VIS spectrometer Lambda 650 equipped with a thermally controlled cell at $22^{\circ} \mathrm{C}$. All experiments were done in triplicate. The DPPH ${ }^{\bullet}$ or $\mathrm{ABTS}^{\bullet+}$ concentrations at steady state (i.e., primary reaction completed and no change in solution for most of compounds) were plotted as a function of the molar concentrations of the lignins or relative phenolic compounds. The antioxidant activity was expressed as a radical deactivation index (RDI) which corresponds to the number of deactivated free radicals per molecule of tested compounds in the case of lignin modeling compounds, or as the number of deactivated free radicals per phenolic $\mathrm{OH}$ group in the case of technical lignins and their fractions. The obtained results are shown as the average with a confidence interval ( $\alpha=0.05$ level of significance). The RDI index is independent of the free radical concentration. The higher the RDI, the higher the free radical scavenging activity.

\subsection{Characterization of the Polymeric and Oligomeric Lignin Products}

\subsubsection{Molecular Weight Distribution}

The molecular weight distribution (MWD) of the parent lignins and the fractions obtained was analyzed by size exclusion chromatography (SEC) described in [66] using the Agilent 1100 system (PaloAlto, CA, USA). Lignin samples dissolved $\left(1 \mathrm{mg} \mathrm{mL}^{-1}\right)$ in the eluent-DMSO-were injected into the PolarGeL-L $300 \times 7.5 \mathrm{~mm}$ column (Polymer Laboratories). The flow rate was $0.8 \mathrm{~mL} \mathrm{~min}^{-1}$, column was thermostated at $60{ }^{\circ} \mathrm{C}$. A differential refractometer (RI) and a UV photometer (at $\lambda=254 \mathrm{~nm}$ ) were used as detectors. For calibration, polystyrene standards were used in the range of 600 to 60,000 Da.

\subsubsection{Analytical Pyrolysis}

The analytical pyrolysis (Py-GC/MS) analysis was performed using a Frontier Lab (Japan) Micro Double-shot Pyrolyser Py-2020iD (500 ${ }^{\circ} \mathrm{C}$ pyrolysis temperature, $600{ }^{\circ} \mathrm{C} \mathrm{s}^{-1}$ heating rate) directly 
coupled with the Shimadzu GC/MS-QP 2010 apparatus (Tokyo, Japan) with capillary column RTX-1701 (Restek, Bellefonte, PA, USA), $60 \mathrm{~m} \times 0.25 \mathrm{~mm} \times 0.25 \mu \mathrm{m}$ film (injector temperature $523 \mathrm{~K}$, ion source $523 \mathrm{~K}$ with EI of $70 \mathrm{eV}$, MS scan range $\mathrm{m} / z 15$ to 350 , carrier gas helium at the flow rate of $1 \mathrm{~mL} \mathrm{~min}{ }^{-1}$, and split ratio of 1:30. The mass of a sample was $1.00-2.00 \mathrm{mg}$. The oven program was $1 \mathrm{~min}$ isothermal at $333 \mathrm{~K}$, then $6 \mathrm{~K} \mathrm{~min}^{-1}$ to 543 , and finally held at $543 \mathrm{~K}$ for $10 \mathrm{~min}$. The apparatus was modified by installation of the splitter of gas carrier flow Vitreous Silica Outlet Splitter VSOS (SGE, Australia) to operate FID and MS detectors simultaneously. The identification of the individual compounds was performed on the basis of GC/MS chromatogram using the Library MS NIST 147.LI13; whereas, the relative area of the peak of individual compounds was calculated using the Shimadzu software on the basis of GC/FID data. The summed molar areas of the relevant peaks were normalized to $100 \%$. Relative peak areas calculated for pyrolysis products of different origin (lignins, carbohydrates, and lipophilic extractives) were used for assessment of the composition of the lignin samples.

\subsubsection{Spectroscopic Analyses}

Fourier transform infrared (FTIR) spectra of lignins were recorded in KBr pellets by Spectrum One apparatus (Perkin Elmer) with $4 \mathrm{~cm}^{-1}$ resolution and 64 scans. ${ }^{1} \mathrm{H}-\mathrm{NMR}$ spectra of the non-acetylated lignin samples were recorded on a BrukerAvance 300 spectrometer (Bruker, Wissembourg, France) operating at $300.1 \mathrm{MHz}$ and at $298 \mathrm{~K}$. The spectra were registered in the hexamethylphosphoroustriamide (HMPT-d18) using a sample concentration of $2.5 \%(w / v)$. Tetramethylsylane (TMS) was used as an internal standard $(\delta=0.00)$. The relaxation delay was $3.0 \mathrm{~s}$ and about 300 scans were collected (90 pulse).

\subsubsection{Functional Analysis}

The content of $\mathrm{OCH}_{3}$ groups in lignin samples was determined by the Viebock-Schwappach method [45]. The results were expressed on a dry weight and ash-free basis. The number of total and phenolic $\mathrm{OH}$ groups was determined, using ${ }^{1} \mathrm{H}-\mathrm{NMR}$ spectroscopy for the acetylated lignin samples [67]. ${ }^{1} \mathrm{H}-\mathrm{NMR}$ spectra were recorded on a Bruker Avance 300 spectrometer (Bruker, Wissembourg, France) operating at $300.1 \mathrm{MHz}$ and at $298 \mathrm{~K}$. The spectra were registered in $\mathrm{CDCl}_{3}$ using typical sample concentrations of $2.5 \%(w / v)$. Tetramethylsylane (TMS) was used as an internal standard $(\delta=0.00)$. The relaxation delay was $3.0 \mathrm{~s}$ and about $300 \mathrm{scans}$ were collected $\left(90^{\circ}\right.$ pulse). The number of phenolic $\mathrm{OH}$ groups with conjugated carbonyl groups was determined by differential UV/VIS spectroscopy. The lignin samples (10-15 mg) were dissolved in $10 \mathrm{~mL}$ dioxane. Two milliliters of the prepared solution was transferred in three 50-mL volumetric flasks. One of the flasks was filled with the buffer solution at $\mathrm{pH} 6$, the second flask was filled with the buffer solution at $\mathrm{pH} \mathrm{12,} \mathrm{and} \mathrm{the} \mathrm{third} \mathrm{flask} \mathrm{was}$ filled with $0.2 \mathrm{M} \mathrm{NaOH}$. The optical density of the prepared alkaline solutions was measured against the optical density of the neutral solution (pH 6) at $300 \mathrm{~nm}$ and $360 \mathrm{~nm}$, using Perkin Elmer UV/Vis spectrometer Lambda 650. (Waltham, MA, USA). Calculations of the number of phenolic OH groups were made as described elsewhere [59].

\subsection{Modification of the Lignins by Reduction of Carbonyl Groups}

The procedure describing the reduction of aldehyde and ketone functions to methylene groups, using the tosylhydrazone derivatives under very mild conditions [68] was adapted for lignin. The yield of the modified lignin was $\sim 75 \%$. Recrystallization from the aqueous methanol provides analytically pure product with the yield $\sim 64 \%$.

\subsection{The Effect of Lignin Products on Thermooxidative Destruction of Polyurethane Films}

Thermooxidative destruction of the model polyurethane (PU) elastomer (control and containing $2 \%$ of lignin sample films) was studied at $310^{\circ} \mathrm{C}$ under isothermal regime by TGA in air atmosphere (flow rate $50 \mathrm{~mL} \mathrm{~min}^{-1}$ ) using the Metler Toledo Star System TGA/ADTA 851e device. A 8-10 mg sample was used. The PU elastomer films were obtained as described previously [33]. 


\section{Conclusions}

In this work, an integrated and multidisciplinary approach for the better understanding the antioxidant activity of lignins has been applied. By combining molecular modeling and antioxidant assays, the antioxidant properties of lignin phenylpropane units were rationalized. The calculation of $\mathrm{O}-\mathrm{H}$ bond dissociation enthalpies (BDE) of characteristic lignin subunits allowed us to quantify the direct influence of key structural features on antioxidant activity of lignin. Importantly, the presence of carbonyl groups conjugated with phenolic units almost completely (98\%) inactivated the antioxidant activity of phenylpropane units. Other structural features, such as aryl ether linkages or carboxyl groups in phenolic units, contributed to a reduction of the redox reactivity to $\sim 30 \%$ or $16-33 \%$ (calculated as normalized $\triangle \mathrm{BDE}$ ), respectively, when compared to an unsubstituted analog. On the other hand, the presence of $-\alpha \mathrm{CH}_{2}-$ or $-\alpha \mathrm{CH}_{3}$ fragments in the side-chains of phenylpropane units resulted in an increase of the redox reactivity of their phenolic groups by approximately $40 \%$ (calculated as normalized $\triangle \mathrm{BDE}$ ).

The antioxidant activity of soda lignins from flax, black alder and ash-tree was also examined. It was suggested that the decrease in heterogeneity and polydispersity, as well as a high content of phenolic $\mathrm{OH}$ groups in the oligomeric fractions of lignins make them good candidates in antioxidation applications. However, such undesirable structural features as high content of carbonyl or carboxyl groups at the alpha or beta positions of the propane chain, drastically decrease the antioxidant capacity of lignins over commercial phenolic type antioxidants. However, the proposed targeted modification of lignins fractions allowed a significant decrease in carbonyl groups conjugated with phenolic structural units, with a simultaneous increase in $\mathrm{CH}_{2}$ groups at $\alpha$-position of the side-chains. This resulted in a drastic increase of the phenolic reactivity making their antioxidant activity competitive with the synthetic commercial antioxidants produced from fossil resources. These modified lignins were more effective in preventing the thermo-oxidation of PU films compare to the reference synthetic antioxidants, therefore appearing as very promising innovative environmentally friendly and biodegradable antioxidation agents.

Author Contributions: Devising of the project, G.T. and P.T.; Conceptualization, G.T. and P.T.; Methodology, T.D., J.P., and D.V.E.; Data Curation, J.P., G.F., and D.V.E.; Visualization, G.F. and D.V.E.; Writing-Original Draft Preparation, J.P., G.F., and P.T.; Writing-Review and Editing, P.T., G.T., and L.L.; DFT calculations and interpretation of the obtained results, G.F. and P.T.; Chemical analysis, synthesis, and characterization of the obtained products, L.L. and T.D.

Funding: Financial support from the Czech Science Foundation (P208/12/G016), the Ministry of Education, Youth and Sports of the Czech Republic (project LO1305), and the student project IGA_PrF_2017_028 of Palacky University is gratefully acknowledged. This study was supported also by the Latvian-France collaboration programme "OSMOZE" and by the Latvian State Institute of Wood Chemistry Bioeconomy grant "LigProBK". This work was supported by CICECO-Aveiro Institute of Materials, POCI-01-0145-FEDER-007679 (FCT Ref. UID/CTM/50011/2013), financed by national funds through the FCT/MEC and when appropriate cofinanced by FEDER under the PT2020 Partnership Agreement.

Acknowledgments: The authors thank Cali (Calcul en Limousin) for computer facilities. The authors are grateful to Maris Lauberts for the help in antioxidant activity tests.

Conflicts of Interest: The authors declare no conflicts of interest.

\section{References}

1. Cheng, F.; Brewer, C.E. Producing jet fuel from biomass lignin: Potential pathways to alkyl-benzenes and cycloalkanes. Renew. Sustain. Energy Rev. 2017, 72, 673-722. [CrossRef]

2. Hou, Q.; Ju, M.; Li, W.; Liu, L.; Chen, Y.; Yang, Q.; Hou, Q.; Ju, M.; Li, W.; Liu, L.; et al. Pretreatment of Lignocellulosic Biomass with Ionic Liquids and Ionic Liquid-Based Solvent Systems. Molecules 2017, $22,490$. [CrossRef] [PubMed]

3. Kai, D.; Tan, M.J.; Chee, P.L.; Chua, Y.K.; Yap, Y.L.; Loh, X.J. Towards lignin-based functional materials in a sustainable world. Green Chem. 2016, 18, 1175-1200. [CrossRef] 
4. Luterbacher, J.S.; Martin Alonso, D.; Dumesic, J.A. Targeted chemical upgrading of lignocellulosic biomass to platform molecules. Green Chem. 2014, 16, 4816-4838. [CrossRef]

5. Ragauskas, A.J.; Beckham, G.T.; Biddy, M.J.; Chandra, R.; Chen, F.; Davis, M.F.; Davison, B.H.; Dixon, R.A.; Gilna, P.; Keller, M.; et al. Lignin valorization: improving lignin processing in the biorefinery. Science 2014, 344, 1246843. [CrossRef] [PubMed]

6. Hu, J.; Zhang, Q.; Lee, D.-J. Kraft lignin biorefinery: A perspective. Bioresour. Technol. 2018, 247, 1181-1183. [CrossRef]

7. Boerjan, W.; Ralph, J.; Baucher, M. L IGNIN B IOSYNTHESIS. Annu. Rev. Plant Biol. 2003, 54, 519-546. [CrossRef]

8. Boeriu, C.G.; Bravo, D.; Gosselink, R.J.A.; van Dam, J.E.G. Characterisation of structure-dependent functional properties of lignin with infrared spectroscopy. Ind. Crops Prod. 2004, 20, 205-218. [CrossRef]

9. Vlaminck, L.; Lingier, S.; Hufendiek, A.; Du Prez, F.E. Lignin inspired phenolic polyethers synthesized via ADMET: Systematic structure-property investigation. Eur. Polym. J. 2017, 95, 503-513. [CrossRef]

10. Vinardell, M.P.; Ugartondo, V.; Mitjans, M. Potential applications of antioxidant lignins from different sources. Ind. Crops Prod. 2008, 27, 220-223. [CrossRef]

11. UGARTONDO, V.; MITJANS, M.; VINARDELL, M. Comparative antioxidant and cytotoxic effects of lignins from different sources. Bioresour. Technol. 2008, 99, 6683-6687. [CrossRef]

12. Bertini, F.; Canetti, M.; Cacciamani, A.; Elegir, G.; Orlandi, M.; Zoia, L. Effect of ligno-derivatives on thermal properties and degradation behavior of poly(3-hydroxybutyrate)-based biocomposites. Polym. Degrad. Stab. 2012, 97, 1979-1987. [CrossRef]

13. Domenek, S.; Louaifi, A.; Guinault, A.; Baumberger, S. Potential of Lignins as Antioxidant Additive in Active Biodegradable Packaging Materials. J. Polym. Environ. 2013, 21, 692-701. [CrossRef]

14. CATIGNANI, G.L.; CARTER, M.E. Antioxidant Properties of Lignin. J. Food Sci. 1982, 47, 1745. [CrossRef]

15. Qazi, S.; Li, D.; Briens, C.; Berruti, F.; Abou-Zaid, M.; Qazi, S.S.; Li, D.; Briens, C.; Berruti, F.; Abou-Zaid, M.M. Antioxidant Activity of the Lignins Derived from Fluidized-Bed Fast Pyrolysis. Molecules 2017, 22, 372. [CrossRef] [PubMed]

16. Morandim-Giannetti, A.A.; Agnelli, J.A.M.; Lanças, B.Z.; Magnabosco, R.; Casarin, S.A.; Bettini, S.H.P. Lignin as additive in polypropylene/coir composites: Thermal, mechanical and morphological properties. Carbohydr. Polym. 2012, 87, 2563-2568. [CrossRef]

17. Fernandes, D.M.; Winkler Hechenleitner, A.A.; Job, A.E.; Radovanocic, E.; Gómez Pineda, E.A. Thermal and photochemical stability of poly(vinyl alcohol)/modified lignin blends. Polym. Degrad. Stab. 2006, 91, 1192-1201. [CrossRef]

18. Canetti, M.; Bertini, F.; De Chirico, A.; Audisio, G. Thermal degradation behaviour of isotactic polypropylene blended with lignin. Polym. Degrad. Stab. 2006, 91, 494-498. [CrossRef]

19. Schmidt, J.A.; Rye, C.S.; Gurnagul, N. Lignin inhibits autoxidative degradation of cellulose. Polym. Degrad. Stab. 1995, 49, 291-297. [CrossRef]

20. Barclay, L.R.C.; Xi, F.; Norris, J.Q. Antioxidant Properties of Phenolic Lignin Model Compounds. J. Wood Chem. Technol. 1997, 17, 73-90. [CrossRef]

21. Gregorová, A.; Cibulková, Z.; Košíková, B.; Šimon, P. Stabilization effect of lignin in polypropylene and recycled polypropylene. Polym. Degrad. Stab. 2005, 89, 553-558. [CrossRef]

22. Domínguez-Robles, J.; Tamminen, T.; Liitiä, T.; Peresin, M.S.; Rodríguez, A.; Jääskeläinen, A.-S. Aqueous acetone fractionation of kraft, organosolv and soda lignins. Int. J. Biol. Macromol. 2018, 106, 979-987. [CrossRef]

23. Park, S.Y.; Kim, J.-Y.; Youn, H.J.; Choi, J.W. Fractionation of lignin macromolecules by sequential organic solvents systems and their characterization for further valuable applications. Int. J. Biol. Macromol. 2018, 106, 793-802. [CrossRef] [PubMed]

24. Brodin, I.; Sjöholm, E.; Gellerstedt, G. Kraft lignin as feedstock for chemical products: The effects of membrane filtration. Holzforschung 2009, 63, 290-297. [CrossRef]

25. Boeriu, C.G.; Fiţigău, F.I.; Gosselink, R.J.A.; Frissen, A.E.; Stoutjesdijk, J.; Peter, F. Fractionation of five technical lignins by selective extraction in green solvents and characterisation of isolated fractions. Ind. Crops Prod. 2014, 62, 481-490. [CrossRef]

26. Thring, R.W.; Griffin, S.L. The heterogeneity of two Canadian kraft lignins. Can. J. Chem. 1995, 73, 629-634. [CrossRef] 
27. Ropponen, J.; Räsänen, L.; Rovio, S.; Ohra-aho, T.; Liitiä, T.; Mikkonen, H.; van de Pas, D.; Tamminen, T. Solvent extraction as a means of preparing homogeneous lignin fractions. Holzforschung 2011, 65, 543-549. [CrossRef]

28. Gosselink, R.J.A.; van Dam, J.E.G.; de Jong, E.; Scott, E.L.; Sanders, J.P.M.; Li, J.; Gellerstedt, G. Fractionation, analysis, and PCA modeling of properties of four technical lignins for prediction of their application potential in binders. Holzforschung 2010, 64, 193-200. [CrossRef]

29. Li, H.; McDonald, A.G. Fractionation and characterization of industrial lignins. Ind. Crops Prod. 2014, 62, 67-76. [CrossRef]

30. Pouteau, C.; Dole, P.; Cathala, B.; Averous, L.; Boquillon, N. Antioxidant properties of lignin in polypropylene. Polym. Degrad. Stab. 2003, 81, 9-18. [CrossRef]

31. Pouteau, C.; Cathala, B.; Dole, P.; Kurek, B.; Monties, B. Structural modification of Kraft lignin after acid treatment: characterisation of the apolar extracts and influence on the antioxidant properties in polypropylene. Ind. Crops Prod. 2005, 21, 101-108. [CrossRef]

32. Jääskeläinen, A.-S.; Liitiä, T.; Mikkelson, A.; Tamminen, T. Aqueous organic solvent fractionation as means to improve lignin homogeneity and purity. Ind. Crops Prod. 2017, 103, 51-58. [CrossRef]

33. Arshanitsa, A.; Ponomarenko, J.; Dizhbite, T.; Andersone, A.; Gosselink, R.J.A.; van der Putten, J.; Lauberts, M.; Telysheva, G. Fractionation of technical lignins as a tool for improvement of their antioxidant properties. J. Anal. Appl. Pyrolysis 2013, 103, 78-85. [CrossRef]

34. Ponomarenko, J.; Dizhbite, T.; Lauberts, M.; Viksna, A.; Dobele, G.; Bikovens, O.; Telysheva, G. Characterization of Softwood and Hardwood LignoBoost Kraft Lignins with Emphasis on their Antioxidant Activity. BioResources 2014, 9, 2051-2068. [CrossRef]

35. An, L.; Wang, G.; Jia, H.; Liu, C.; Sui, W.; Si, C. Fractionation of enzymatic hydrolysis lignin by sequential extraction for enhancing antioxidant performance. Int. J. Biol. Macromol. 2017, 99, 674-681. [CrossRef]

36. Brunow, G.; Kilpeläinen, I.; Sipilä, J.; Syrjänen, K.; Karhunen, P.; Setälä, H.; Rummakko, P. Oxidative Coupling of Phenols and the Biosynthesis of Lignin. In Lignin and Lignan Biosynthesis; American Chemical Society: Washington, DC, USA, 1998; pp. 131-147.

37. Önnerud, H.; Gellerstedt, G. Inhomogeneities in the Chemical Structure of Hardwood Lignins. Holzforschung 2003, 57, 255-265. [CrossRef]

38. Pan, X.; Kadla, J.F.; Ehara, K.; Gilkes, N.; Saddler, J.N. Organosolv Ethanol Lignin from Hybrid Poplar as a Radical Scavenger: Relationship between Lignin Structure, Extraction Conditions, and Antioxidant Activity. J. Agric. Food Chem. 2006, 54, 5806-5813. [CrossRef] [PubMed]

39. Anouar, E.; Košinová, P.; Kozlowski, D.; Mokrini, R.; Duroux, J.L.; Trouillas, P. New aspects of the antioxidant properties of phenolic acids: a combined theoretical and experimental approach. Phys. Chem. Chem. Phys. 2009, 11, 7659. [CrossRef] [PubMed]

40. Anouar, E.; Calliste, C.A.; Košinová, P.; Di Meo, F.; Duroux, J.L.; Champavier, Y.; Marakchi, K.; Trouillas, P. Free Radical Scavenging Properties of Guaiacol Oligomers: A Combined Experimental and Quantum Study of the Guaiacyl-Moiety Role. J. Phys. Chem. A 2009, 113, 13881-13891. [CrossRef]

41. Di Meo, F.; Lemaur, V.; Cornil, J.; Lazzaroni, R.; Duroux, J.-L.; Olivier, Y.; Trouillas, P. Free Radical Scavenging by Natural Polyphenols: Atom versus Electron Transfer. J. Phys. Chem. A 2013, 117, 2082-2092. [CrossRef]

42. Setzer, W.N. Lignin-derived oak phenolics: a theoretical examination of additional potential health benefits of red wine. J. Mol. Model. 2011, 17, 1841-1845. [CrossRef]

43. Kjällstrand, J.; Petersson, G. Phenolic antioxidants in wood smoke. Sci. Total Environ. 2001, 277, 69-75. [CrossRef]

44. Kozlowski, D.; Trouillas, P.; Calliste, C.; Marsal, P.; Lazzaroni, R.; Duroux, J.-L. Density Functional Theory Study of the Conformational, Electronic, and Antioxidant Properties of Natural Chalcones. J. Phys. Chem. A 2007, 111, 1138-1145. [CrossRef]

45. Kozlowski, D.; Marsal, P.; Steel, M.; Mokrini, R.; Duroux, J.-L.; Lazzaroni, R.; Trouillas, P. Theoretical Investigation of the Formation of a New Series of Antioxidant Depsides from the Radiolysis of Flavonoid Compounds. Radiat. Res. 2007, 168, 243-252. [CrossRef]

46. Calliste, C.A.; Kozlowski, D.; Duroux, J.L.; Champavier, Y.; Chulia, A.J.; Trouillas, P. A new antioxidant from wild nutmeg. Food Chem. 2010, 118, 489-496. [CrossRef] 
47. Bortolomeazzi, R.; Verardo, G.; Liessi, A.; Callea, A. Formation of dehydrodiisoeugenol and dehydrodieugenol from the reaction of isoeugenol and eugenol with DPPH radical and their role in the radical scavenging activity. Food Chem. 2010, 118, 256-265. [CrossRef]

48. Ragnar, M.; Lindgren, C.T.; Nilvebrant, N.-O. $\mathrm{pK}_{\mathrm{a}}$-Values of Guaiacyl and Syringyl Phenols Related to Lignin. J. Wood Chem. Technol. 2000, 20, 277-305. [CrossRef]

49. Rived, F.; Rosés, M.; Bosch, E. Dissociation constants of neutral and charged acids in methyl alcohol. The acid strength resolution. Anal. Chim. Acta 1998, 374, 309-324. [CrossRef]

50. Stella, A.O.; Maria, Z.T.; Anastasios, P.V.; Evangelos, G.B. Structure-DPPH• Scavenging Activity Relationships: Parallel Study of Catechol and Guaiacol Acid Derivatives. J. Agric. Food Chem. 2006, 54, 5763-5768.

51. Villaño, D.; Fernández-Pachón, M.S.; Moyá, M.L.; Troncoso, A.M.; García-Parrilla, M.C. Radical scavenging ability of polyphenolic compounds towards DPPH free radical. Talanta 2007, 71, 230-235. [CrossRef]

52. Kanitskaja, L.V.; Medvedeva, S.A.; Ivanova, S.Z.; Kushnarev, D.F.; Ri, B. 1H NMR spectroscopy as a method for the identification of hydroxyl-containing lignin fragments. Khimija Drev. 1987, 6, 3-10.

53. Li, S.; Lundquist, K. A new method for the analysis of phenolic groups in lignins by ' $\mathrm{H}$ NMR spectrometry. Nord. Pulp Pap. Res. J. 1994, 9, 191-195. [CrossRef]

54. Irganox@1010. Available online: https://worldaccount.basf.com/en_GB/welcome.html (accessed on 5 April 2019).

55. Chattopadhyay, D.K.; Webster, D.C. Thermal stability and flame retardancy of polyurethanes. Prog. Polym. Sci. 2009, 34, 1068-1133. [CrossRef]

56. Mottern, H.O. A New Vanillin Synthesis. J. Am. Chem. Soc. 1934, 56, 2107-2108. [CrossRef]

57. Rab, M.Z. The synthesis of lignin models, containing.- $\beta$-ether bond. For. J. 1968, 6, 120-123. (In Russian)

58. Erdtman, H.; Leopold, B.; Linderholm, H.; Kainulainen, A.; Halonen, A.; Pulkkinen, E. Aromatic Keto- and Hydroxy-polyethers as Lignin Models. II. Acta Chem. Scand. 1949, 3, 1358-1374. [CrossRef]

59. Zakis, G.F. Functional Analysis of Lignins and Their Derivatives; TAPPI Press: Atlanta, GA, USA, 1994; ISBN 0898522587.

60. Abächerli Alfred, D.F. Method for Preparing Alkaline Solutions Containing Aromatic Polymers 1998. U.S. Patent 6,239,198, 20 March 1998.

61. Arshanitsa, A.; Krumina, L.; Telysheva, G.; Dizhbite, T. Exploring the application potential of incompletely soluble organosolv lignin as a macromonomer for polyurethane synthesis. Ind. Crops Prod. 2016, 92, 1-12. [CrossRef]

62. Trouillas, P.; Marsal, P.; Siri, D.; Lazzaroni, R.; Duroux, J.-L. A DFT study of the reactivity of OH groups in quercetin and taxifolin antioxidants: The specificity of the 3-OH site. Food Chem. 2006, 97, 679-688. [CrossRef]

63. Trouillas, P.; Marsal, P.; Svobodová, A.; Vostálová, J.; Gažák, R.; Hrbáč, J.; Sedmera, P.; Křen, V.; Lazzaroni, R.; Duroux, J.-L.; et al. Mechanism of the Antioxidant Action of Silybin and 2,3-Dehydrosilybin Flavonolignans: A Joint Experimental and Theoretical Study. J. Phys. Chem. A 2008, 112, 1054-1063. [CrossRef]

64. Gaussian 09; Gausian, Inc.: Wallingford, CT, USA, 2010.

65. Baltrušaitytè, V.; Venskutonis, P.R.; Čeksterytè, V. Radical scavenging activity of different floral origin honey and beebread phenolic extracts. Food Chem. 2007, 101, 502-514. [CrossRef]

66. Ringena, O.; Lebioda, S.; Lehnen, R.; Saake, B. Size-exclusion chromatography of technical lignins in dimethyl sulfoxide/water and dimethylacetamide. J. Chromatogr. A 2006, 1102, 154-163. [CrossRef] [PubMed]

67. Evtuguin, D.V.; Neto, C.P.; Silva, A.M.; Domingues, P.M.; Amado, F.M.; Robert, D.; Faix, O. Comprehensive study on the chemical structure of dioxane lignin from plantation Eucalyptus globulus wood. J. Agric. Food Chem. 2001, 49, 4252-4261. [CrossRef] [PubMed]

68. Caglioti, L. Reduction of Ketones by Use of the Tosylhydrazone Derivatives: Androstan-17 b-ol. Org. Synth. 1972, 52, 122.

Sample Availability: Samples of the compounds are not available from the authors. 